\title{
Tax Competition, Fiscal Policy, and Public Debt Levels in a Monetary Union
}

\author{
Séverine Menguy ${ }^{1+}$ \\ ${ }^{1}$ Université de Paris, France
}

\begin{abstract}
We study the link between tax competition, efficiency of available fiscal bases and public indebtedness levels in the member countries of a monetary union. Theoretically, labor taxation would be the most efficient way to collect fiscal resources, as this production factor is more rigid; so, only initially weakly indebted countries can afford to have weak labor taxation rates. Empirical data also validate the decreasing relation between consumption taxation rates and public debt levels. On the contrary, capital taxation would be less efficient, because of capital mobility. If the capital taxation rate is higher than in the rest of the monetary union, tax evasion could deteriorate the fiscal base and increase the public debt to GDP ratio. So, empirical data show an ambiguous trend between the historical evolution of implicit capital taxation rates and public debt levels in the Euro Area.
\end{abstract}

Keywords: capital taxation rate, labor taxation rate, consumption taxation rate, public debt, monetary union, tax competition

\section{Introduction}

The economic literature has largely studied tax competition consequences and dangers, particularly monetary unions, which accentuate financial and commercial interdependencies. For example, in the context of the European Economic and Monetary Union (EMU) tax competition was feared to conduct a "race to the bottom" (Sorensen, 2001; Zodrow, 2006; Bretschger \& Hettich, 2002). This condition reduces effective tax rates on mobile fiscal bases (capital) and excessively increases tax rates on immobile fiscal bases (labor and land). Therefore, capital mobility reduces source countries' incentive and residence countries' ability to tax mobile activities. Residence countries struggle with monitoring and taxing accrued foreign investment income. Furthermore, source countries hesitate to impose high taxes on inward foreign investment for fear of capital flight. Therefore, governments' attempts to attract mobile capital may trigger international tax competition. Taxation and public spending during this time are driven below 
optimal levels. Furthermore, living within a monetary union has probably increased the degree of factor mobility such as that of EMU member states, particularly regarding capital.

The destination principle of taxation of consumption usually prevails, that is, exports are not taxed by the exporting country but by the importing country. Origin-based taxation system is applied to cross-border shopping only, which has a negligible total trade share. Similarly, recent labor mobility remains significantly low in Europe. Therefore, tax competition mainly concerns capital production. Economic literature evidence shows that capital movements have increasingly become responsive to capital taxation levels. This finding implies high degree of tax competition among EMU member states. For example, a country may implement a "beggar-thy-neighbor" policy on capital taxation (highly mobile factor), which reduces tax rates, to attract a larger tax base. Then, tax rates are fixed un-cooperatively at an inefficiently low level. Therefore, this type of tax competition was feared from the start of EMU's creation.

Empirically, this apprehension does not apply to nearly null capital tax rates as capital is not a completely mobile production factor. Capital cannot move easily between countries if it concerns production of non-tradable goods and services or if a country can benefit from location rental. This condition applies when production technology requires specific and high-skilled workers, who are less likely mobile. A country's competitiveness (agglomeration forces) and other strategies also determine capital inflows. Thus, despite tax competition, capital taxation should remain in the future at non-negligible levels to capture unusual profits and location rents (Sorensen, 2006). Moreover, political forces and motivations may also avoid decrease in capital tax rates below a given level while capital taxation continues in all major economies. Nevertheless, significantly low corporate tax rates are observed in Ireland and in new EMU state members (e.g., Latvia and Lithuania). Furthermore, open countries, particularly monetary unions, are susceptible to tax competition consequences. It is noteworthy that the effect of financial globalization on public debt level and on governments' ability to redistribute is an important but partially understood issue.

How does high economic integration impact the capital production factor? The "efficiency hypothesis" holds that national tax rates on mobile factors is eroded when competing for mobile tax bases. Mobile factors' (capital) source-based tax appears counter-productive and inefficient as it could strongly decrease the fiscal base (capital stock). Thus, this potential capital outflow implies that fiscal burden mainly relies on local residents through high labor and land property taxes or high non-tradable good prices. This approach is applied by countries that aim to maintain certain fiscal resource and production levels of public goods and services. In addition, the "compensation hypothesis" holds that governments increase their social welfare expenditure to insure citizens against increased economic risks from globalization. Therefore, the impacts of tax competition on public debt redistribution issues and evolution are more significant than the danger it poses on decreasing tax rates on mobile fiscal bases to excessively low and near 
zero levels.

The economic literature has shown that increased capital mobility and tax competition have shifted the fiscal burden to labor as capital taxes are reduced to attract more mobile capital and increase the fiscal base. Labor and consumption tax bases are significantly immobile and may not reach abroad to avoid the fiscal burden. However, Genschel (2001) holds that if tax rates on more immobile bases are extremely high, then a high unemployment rate or shadow economy may represent another type of fiscal evasion. Thus, tax competition prevents governments from utilizing important capital tax revenue sources and compels them to rely more on labor taxation to meet fiscal resources targets. This condition negatively impacts employment and growth and a possible redistributive economic policy. According to the author, internal pressures aim to avoid excessive weight on labor production factor. As a result, public deficit and debt, austerity, and unemployment rate increase, whereas the shadow economy intensifies with tax competition. Therefore, this current study aims to explore the potential consequences of tax competition on the evolution of the budgetary deficit and public debt in the context of a monetary union. We conduct a simple analytical model to highlight the consequences of tax structure between consumption, labor, and capital taxes in a member country of a monetary union on the potential evolution of its public indebtedness level.

The study mainly finds that, theoretically, labor taxation is the most efficient way for fiscal resource collection in a monetary union as this production factor is rigid. Thus, weakly indebted countries can initially afford to have weak labor tax rates. On the contrary, capital taxation is less efficient because of capital mobility. If capital tax rate is higher than in the rest of the monetary union, then tax evasion could deteriorate the fiscal base and increase the public debt to gross domestic product (GDP) ratio.

The rest of the paper is organized as follows. The second section provides a review of the economic literature's results regarding the links between fiscal policy, tax competition, and public debt levels in a monetary union's member countries. The third section describes the New Keynesian model to shed light on economic agents and the model's global equilibrium. The fourth section defines the theoretical economic and fiscal (capital, consumption, and labor tax rates) factors that influence public debt level. The fifth section reviews empirical data related to the link between tax rates and public debt levels. Finally, the sixth section concludes the paper.

\section{Economic Literature Review}

One of the main results of the economic literature is the impact of tax competition on fiscal policy instruments in that it shifts the fiscal burden from mobile to less mobile fiscal bases. High capital mobility generates a race to the bottom on source-based mobile capital taxes. 
Consequently, corporate tax rates are expected to depend negatively on the degree of capital mobility, whereas taxes on immobile labor increase. In this context, Sorensen (2001) mentions that labor taxes (labor-related personal income taxes, payroll taxes, and social security taxes) increased between the 1980s and 1990s, whereas capital taxes (corporate income taxes and personal income taxes on property, wealth, etc.) were more stable. Therefore, even when tax competition does not conduct an under-provision of public goods, tax burden is unequally distributed to the detriment of immobile labor.

Zodrow (2006) also examines capital income taxation in a small open economy with highly elastic internationally mobile capital supply and increasing tax competition. As many authors, he underlines that source-based capital income taxes (corporate income tax) are undesirable, because it is a highly distortionary tax instrument relative to other potential revenue sources. Thus, local production factors (immobile labor and land) completely take the capital income tax burden, including its efficiency costs, because capital is mobile and can migrate to other countries if tax rates are excessively high. Similarly, Bretschger and Hettich (2002) show that globalization positively impacts the ratio of effective labor tax rate to corporate tax rate. Their finding verifies the shift from corporate tax to less mobile tax bases in Organization for Economic Cooperation and Development (OECD) countries. They study a panel of 14 OECD countries for the period 1967-1996 and find that globalization (the world economy's integration indicator) negatively and significantly impacts statutory corporate taxes and likely raises labor taxes, which are less elastic.

Sorensen (2003) also shows that when international capital flows increased considerably between 1985 and 1995, the higher overall tax burden experienced in most countries was concentrated on labor. This finding suggests that increasing capital mobility induced governments to raise the relative tax burden on more immobile labor factor. The author shows that between the 1970s and 1990s, a broadening corporate tax base has approximately offset decreasing statutory corporate tax rates. Thus, corporate tax revenues in most countries have been fairly stable as a fraction of GDP. Similarly, Haufler et al. (2006) use empirical data for 23 OECD countries between 1980 and 2001 and show that countries reduce their corporate tax rate relative to labor tax rate, when either public good preferences (public consumption share in GDP) increase or multinational firms employ an increasing capital share. Empirically, Krogstrup (2004) also uses a global multi-aspect capital mobility index (Quinn's index), and he shows robust evidence of tax competition effect on corporate tax burdens in 13 European Union (EU) countries between 1980 and 2001.

Similarly, Azémar and Hubbard (2015) use the Bureau of Labor Statistics data on 13 OECD countries between 1980 and 2004 in their econometric analysis, and they show that substantial corporate tax burden is shifted from capital to labor. They find that a $1 \mathrm{pp}$ increase in corporate taxes decreases wages by approximately $0.1 \%$, depending on country characteristics. Thus, the 
decrease in domestic capital reduces domestic workers' productivity. This condition translates (indirect effect) into lower wages at home. Therefore, the authors hold that the lower the domestic labor's burden, the lower is the degree of trade openness, but the higher is a country's relative position in the world capital market.

Felix (2017) uses data of 30 countries between 1979 and 2002 and estimates that a 1 pp increase in marginal corporate tax rate of high-income countries reduces mean annual gross wages by $0.7 \%$. This change concerns low- and high-skilled workers' wages to the same degree. Hassett and Mathur (2006) also investigate the incidence of various corporate tax rate measures on manufacturing wages using panel data across 72 developed and developing countries between 1981 and 2002. They find that a $1 \%$ decrease in statutory corporate tax rate increases wages by $0.95 \%$ on average across the estimations. Moreover, the magnitude of the impact is amplified for poor and small economies. On the contrary, the authors do not find any effect of personal income tax rates on wages. Lastly, Arulampalam et al. (2008) examine companies in nine European countries during 1996-2005 and underline the importance of wage bargaining process between employers and trade-unions on value added tax sharing. They find that a $\$ 1$ exogenous corporate tax increase reduces the wage bill by 75 cents in the long run based on a given value added tax to be shared.

However, despite the tendency to shift the fiscal burden to less mobile fiscal bases, developed countries and the biggest European countries' capital taxation rates have remained at non-negligible levels (including in the future) due to "location-specific rents". Baldwin and Krugman (2004) use a panel data set on Western European countries and show that agglomeration forces can reverse standard international tax competition results. The reason is because they create taxable quasi-rents without inducing delocalization. This finding suggests that taxation is subtler than a race to the bottom. Thus, advanced nations benefit from advantages such as an established infrastructure base and accumulated experience. This condition implies favorable external economies of scale that allow them to have higher tax rates, including on mobile capital, than less advanced nations. Similarly, Cai and Treisman (2005) show that if countries have sufficiently heterogeneous natural resources, geographical location, inherited human capital, or infrastructure, then capital mobility often weakens poorly endowed units' discipline and increases policy divergence. Better-endowed units invest substantially in infrastructure and are rewarded by capital inflows, whereas poorly endowed units may be less business-friendly or more corrupt than under capital immobility.

Therefore, many papers show that local market and host countries' institutional conditions influence multinational firms' location decisions. Fundamental factors include proximity to markets, various primary and intermediate input costs, local labor markets' skill levels, local competition, legal and regulatory environments, and degree of political stability, which includes commitment credibility to enforce property rights. For example, Garretsen and Peeters (2006) 
study 19 OECD countries between 1981 and 2001 and find that increased international capital mobility (measured by FDI volume) implies low corporate tax rate. Nevertheless, they underline that core countries can afford higher tax rates compared with peripheral countries due to economies of agglomeration (measured by population per $\mathrm{km}^{2}$ ).

Kind et al. (2000) also use a new economic geography model to analyze tax competition between two countries that aim to attract internationally mobile capital. They find that if industry is concentrated in one of the countries, the host country may increase its welfare per capita by setting a higher source tax on capital and capturing positive externalities arising from the agglomeration. As a result, capital becomes effectively immobile. According to Sorensen (2006), location-specific rents are generated from natural resources, an attractive infrastructure, availability of a pool of qualified labor, and agglomeration forces. Whereas "normal" capital returns are difficult to tax and tend to vanish, these location-specific rents on capital may continue to be taxed in the future.

Therefore, many papers find that tax competition did not imply a significant decrease in capital tax rates. For example, Devereux and Sorensen (2006) show that statutory corporate tax rates have fallen substantially and continuously since the early 1980s. However, tax bases were broadened between the early 1980s and the end of the 1990s. Therefore, corporate income tax revenues weighted by GDP have remained broadly stable on average as a proportion of GDP between 1965 and 2000. Nevertheless, corporate income tax revenues have declined as a proportion of total tax revenue since 1965. Similarly, Devereux et al. (2002) note that average statutory corporate income tax rates in the EU and the United States fell dramatically from $48 \%$ in 1982 to $35 \%$ in 2001 . However, they show that in the EU and G7 countries, between 1980 and 2002, effective marginal tax rates have remained fairly stable on average due to tax-cutting and base-broadening (less generous allowance rates) reforms.

Hines (2007) also shows that corporate tax collections are remarkably persistent relative to GDP, government revenues, and other economic activity and government need indicators, despite growing international capital mobility and various fiscal practices to attract this capital. The author holds that less mobile national capital has continued to be highly taxed, whereas tax burden has decreased to attract more mobile international investors. Corporate tax revenues as a fraction of GDP in OECD countries have been approximately constant over the past 40 years (Devereux, 2007) and have increased around 2010. Bond et al. (2000) also show that between 1980 and 2000, corporate tax revenues have not decreased in proportion of GDP. Slemrod (2004) also finds that increase in openness and international competitive pressures are negatively associated with statutory corporate rates between 1980 and 1995 . However, he finds evidence that a country's revenue needs (expenditure-GDP ratio) do not influence corporate tax rate.

Besides, a period of strong corporate tax rate reductions occurred around the time of the 
Eastern enlargement of the EU. Nevertheless, this process has been slowed down significantly after 2005. Completion of a single market increased Europe's attractiveness for international investment. Thus, EU member states could reasonably maintain their moderate corporate taxation level in the future, regardless of international tax competition. If capital mobility puts a downward pressure on statutory corporate tax rates, highly integrated and open countries may increase capital tax rates to tax foreign firms and export part of the fiscal burden to these big multinationals (tax exportation effect). Indeed, by broadening the tax base, effective capital tax rates (capital tax share in GDP) remained high regardless of the decrease in statutory tax rates between 1980 and the 2000s (Sorensen, 2000, 2006).

Moreover, Mendoza and Tesar (2005) use empirical data of the G7 countries between 1971 and 1995. They find that cross-country tax competition occurs as financial liberalization increases the covariance and co-movement between taxation rates in the G7 countries, resulting in their welfare loss. The authors also find that indirect tax harmonization is undesirable because it forces countries to respond to the adverse effects of tax competition on tax revenues by raising highly distorting labor income taxes. By contrast, tax harmonization on immobile factors and freedom to adjust consumption taxes to offset lost tax revenue from capital income tax competition would be highly desirable. Therefore, the authors of this study emphasize the consequences of tax competition on fiscal resource redistribution, that is, certain risks may arise from increasing the budgetary deficit and public debt.

Similarly, Arcalean (2017) finds that international financial liberalization increases capital mobility and hinders periodical capital-labor redistribution. Substantial fiscal burden share is shifted from capital to labor. Therefore, public debt increase can reduce the overall labor tax burden and increases redistribution. Hence, strong tax competition leads to a fiscal deficit bias at the early stages of financial liberalization, for countries that participate in the integrated capital market. International asymmetries in capital mobility also lead to external imbalances and diverging cross-country fiscal deficits.

Furthermore, Janeba and Todtenhaupt (2016) develop a simple fiscal competition model with government borrowing. A government may experience borrowing constraints due to a possible default or common fiscal discipline rules (such as the European Fiscal Compact). Therefore, a government responds optimally to these conditions by lowering durable public infrastructure spending, inducing a more aggressive tax setting. Thus, the model may help explain why highly indebted European countries have decreased corporate tax rates over-proportionally and have continuously deteriorating infrastructure. In addition, capital tax rate cut can become highly aggressive if the high inherited public debt level is due to high previous public consumption expenditure, with insufficient public infrastructure investment.

Based on these studies, the current paper aims at shedding a new light on the links between monetary unions' tax competition and public debt levels. Moreover, we aim to show how high 
financial integration and tax competition impact fiscal policies and public debt levels of monetary unions' member countries.

\section{The Model}

Our study will adopt the standard New Keynesian model using a representative household, firm, and government in a given country $(i)$. We aim to analyze EMU specificities by exploring a monetary union in an open economy, where countries share the same currency and central bank. Therefore, our model considers the situation of a given country (i), whereas the country $(j)$ represents all other countries and the rest of the entire monetary union.

We suppose perfectly competitive economies, integrated goods market, and homogeneous good production. We assume complete national and international financial markets of the monetary union (risks are completely shared among households), mobile financial capital, and countries' common interest rate. This common interest rate is defined by a common central bank's monetary policy, whereas each government defines autonomously its fiscal policy (public expenditure, tax revenues, and public debt). Each member country's government maximizes the utility of a representative consumer/household. Therefore, public expenditure is set as an endogenous variable in our model. Moreover, labor markets are segmented and labor is immobile across countries Each country may levy taxes on wage (including social security taxes) and capital income and indirect taxes on consumption. Income distribution issues are ignored by assuming that either each region's residents are identical or a representative consumer's preferences depict their aggregate welfare. Productivity, taxation rates, public expenditure, or public indebtedness can differ between countries, whereas for simplicity, they share the same preferences and structural parameters.

Furthermore, the current paper supposes source-based capital taxation. Empirically taxing residents on their worldwide capital income equally based on the residence principle is difficult due to administrative and tax compliance problems involved with foreign-source income taxation, imperfect information exchange among tax authorities, and persistent bank secrecy laws among others. Besides, many residence countries with corporate income taxation explicitly exempt foreign-source income from domestic tax if the foreign income originates from a tax treaty partner country. In addition, most other countries only tax their "resident" multinationals' foreign-source income to the extent that it is repatriated to the parent company. Moreover, this taxation is applied only to the extent domestic tax liability exceeds the source tax that has already been paid to the foreign country. Thus, we hypothesize that, with regard to corporate capital tax, foreign-source income tax is not levied on a country's residents, whereas foreigners and residents' domestic-source income are equally taxed. 


\section{A. Representative consumer}

Aggregate demand for country $(i)$ results from the log-linearization of the Euler equation, which describes the representative household's expenditure decisions. The representative household in the country $(i)$ provides labor and consumes goods. In a given period $(T)$, it maximizes intertemporal utility function as follows:

$$
\max \sum_{t=T}^{\infty} \beta^{t-T} E_{T}\left[U_{i, t}\right]
$$

Where $\left(E_{t}\right)$ is the rational expectation operator conditional on information available at date $(t)$ and $(\beta)$ is the time discount factor. Interest rates, taxation rates, prices, and wages are then taken as given by the representative household.

A representative household's utility function is assumed as follows:

$$
U_{i, t}=\alpha_{c} \log \left(C_{i, t}\right)+\alpha_{g} \log \left(G_{i, t}\right)-\alpha_{l} \frac{1}{(1+\varphi)} L_{i}^{(1+\varphi)}
$$

Where $\left(C_{i, t}\right)$ is the real private good consumption, $\left(G_{i, t}\right)$ is the real public expenditure (public good consumption), and $\left(L_{i}\right)$ is the labor supply (fixed immobile labor).

Indices $\left(0<\alpha_{c}<1\right),\left(0<\alpha_{g}<1\right)$, and $\left(0<\alpha_{l}<1\right)$ are the weights given by the representative consumer to consumption of private goods, public goods, and leisure, respectively.

Utility is an increasing and concave function of $\left(C_{i, t}\right)$, that is, an index of the household's private consumption of all supplied goods, and of public goods and services provided in the home country $\left(G_{i, t}\right)$. Utility is also a decreasing and convex function of labor supply $\left(L_{i}\right)$, where $(\varphi \geq 0)$ is the inverse of the Frisch elasticity of labor supply. To simplify, we suppose this model has identical labor supply and demand. In other words, we avoid the question of the effect of labor taxation on employment decisions from firms and on the arbitrage of workers between labor supply and leisure decisions.

This maximization is subject to the life-time and intertemporal budgetary constraint. If we suppose complete financial markets, then the flow budget constraint for each period $(T)$ of the representative consumer in country $(i)$ is as follows:

$$
\begin{aligned}
\left(1+t_{i}^{c}\right) P_{i, T} C_{i, T} & +P_{i, T} I N V_{i i, T}+P_{j, T} I N V_{i j, T}+B_{i, T}=\left(1-t_{i}^{k}\right)\left(R_{T}-\delta P_{i, T}\right) K_{i, T}^{s} \\
& +\left(1-t_{j}^{k}\right)\left(R_{T}-\delta P_{j, T}\right) K_{i j, T}^{s}+\left(1-t_{i}^{l}\right) W_{i, T} L_{i}+\left(1+R_{T-1}\right) B_{i, T-1}
\end{aligned}
$$

Where in country $(i)$ during period $(t),\left(I N V_{i j, t}\right)$ is the households' real investment from 
country $(i)$ in a new physical capital in country $(j),\left(K_{i j, t}^{s}\right.$ is the households' physical capital in country $(i)$ invested in country $(j),\left(P_{i, t}\right)$ is the consumer prices, $\left(W_{i, t}\right)$ is the nominal wage rate, $\left(R_{t}\right)$ is the nominal interest rate common to all countries in the monetary union, $\left(B_{i, t}\right)$ is the nominal value of government bonds and public debt at the end of period $(t),(\delta)$ is the depreciation rate of physical capital, $\left(t_{i}^{l}\right)$ is the labor taxation rate, $\left(t_{i}^{c}\right)$ is the consumption taxation rate, and $\left(t_{i}^{k}\right)$ is the capital taxation rate.

The representative consumer of country (i) may consume his/her non-human wealth immediately or invest it on the capital market and consume it at the end of the period. Thus, he/she consumes private goods and invests in capital or purchases government bonds, with regard to expenditures. His/her revenue share not spent on private good consumption (saving) is the amount available to capital market investment. Regarding resources, the representative consumer receives labor (wage) and capital (interest rate) revenues. We suppose that households rent capital to firms, for which they receive a rental rate. The representative consumer also gains from government bonds holding from the previous period. For simplicity, we suppose that these financial assets are only risk-free one-period government bonds and that domestic consumers completely own public debt of country $(i)$. Moreover, capital is not completely taxed; physical capital depreciation is exempted from taxation.

In this context, Equation (1) is maximized through Equation (2) under constraint (3). The result implies the following first-order Euler condition regarding timing of expenditure decisions and intertemporal substitution for period $(T)^{1)}$ :

$$
\frac{\partial U_{i, T}}{\partial C_{i, T}}=\frac{\beta^{k} E_{T}\left[\left(1+R_{T+k-1}\right) \cdots\left(1+R_{T}\right)\right] P_{i, T}}{E_{T}\left(P_{i, T+k}\right)} \frac{\partial E_{T}\left(U_{i, T+k}\right)}{\partial C_{i, T+k}}
$$

Then, by combining Equations (2) and $(4),\left(\mathrm{V}_{T}\right)$, and $\left(\mathrm{V}_{k}\right)$, we obtain the following:

$$
C_{i, T}=\frac{E_{T}\left(P_{i, T+k}\right)}{\beta^{k} E_{T}\left[\left(1+R_{T+k-1}\right) \cdots\left(1+R_{T}\right)\right] P_{i, T}} E_{T}\left(C_{i, T+k}\right)
$$

Thus, in the logarithms, with $\log (1+x) \sim x$ if $(x)$ is small, and $\left[\pi_{i, t}=p_{i, t}-p_{i, t-1}=\frac{P_{i, t}-P_{i, t-1}}{P_{i, t-1}}\right]$ as the inflation rate for consumption prices, Equation (5) implies the following:

1) Summing Equation (3) to have an intertemporal budgetary constraint and using Equation (10) with $\lim _{T \rightarrow \infty} B_{i, T}=0$, we obtain the following:

$\left(1+t_{i}^{c}\right) P_{i, T} C_{i, T}+E_{T}\left[\sum_{t=T}^{\infty} \frac{\left(1+t_{i}^{c}\right) P_{i, t+1} C_{i, t+1}}{\left(1+R_{t}\right) \cdots\left(1+R_{T}\right)}\right]+f\left(\sum_{t=T}^{\infty} K_{i i, T}^{s}, \sum_{t=T}^{\infty} K_{i j, T}^{s}\right)=\left(1-t_{i}^{l}\right) W_{i, T} L_{i}+E_{T}\left[\sum_{t=T}^{\infty} \frac{\left(1-t_{i}^{l}\right) W_{i, t+1}}{\left(1+R_{t}\right) \cdots\left(1+R_{T}\right)}\right] L_{i}+\left(1+R_{T-1}\right) B_{i, T-1}$ 


$$
c_{i, T}=E_{T}\left(c_{i, T+1}\right)-\left[R_{T}-E_{T}\left(\pi_{i, T+1}\right)\right]
$$

Therefore, private consumption increases with expected future consumption and decreases with real interest rate.

Furthermore, Equation (2) implies the following optimal substitution (such as $\partial U_{i, T}=0$ ) for the representative consumer in country $(i)$ between private and public consumption:

$$
G_{i, T}=-\frac{\alpha_{g}}{\alpha_{c}}\left(\frac{\partial G_{i, T}}{\partial C_{i, T}}\right) C_{i, T}
$$

Thus, regarding private and public consumption variation, based on Equation (7), in the logarithms, and in terms of variations, we obtain the following:

$$
g_{i, T}=c_{i, T}
$$

Therefore, private and public consumption should increase at the same pace. Moreover, for a given labor supply level (we take a country's demographic situation and population size), Equation (2) holds that the public debt which maximizes the representative consumer's utility in country $(i)\left[\frac{\partial U_{i, t}}{\partial B_{i, t}}=0\right]$ verifies the following:

$$
-\alpha_{c} G_{i, t}\left(\frac{\partial C_{i, t}}{\partial B_{i, t}}\right)=\alpha_{g} C_{i, t}\left(\frac{\partial G_{i, t}}{\partial B_{i, t}}\right)
$$

Thus, if public indebtedness decreases, then loss due to weaker purchasing power and private consumption with a higher tax rate and higher fiscal resources, must equal the gains from higher provided public services if the public debt level increases. The marginal transformation rate between private and public consumption must balance their marginal substitution rate in the representative consumer's utility function.

Finally, we suppose that capital stock varies according to the following equation:

$$
E_{t}\left(K_{i j, t+1}\right)=(1-\delta) K_{i j, t}+I N V_{i j, t}
$$

Thus, in logarithms and in terms of variations, capital stock adjusts as follows:

$$
E_{t}\left(k_{i j, t+1}\right)=(1-\delta) k_{i j, t}+\left(\frac{I N V_{i j}}{K_{i j}}\right) i n v_{i j, t}=(1-) k_{i j, t}+\delta i n v_{i j, t}
$$




\section{B. Representative firm}

We suppose a continuum of firms in country $(i)$. The representative firm adapts product differentiation in a monopolistic competition setting. Monopolistic competition provides goods suppliers a market power on price -setting while fitting the empirical evidence of numerous firms in the economy. Country ( $i$ )'s representative firm utilizes two production factors, namely, capital (from domestic and foreign source) and labor, with respective production function share $(0<\nu<1)$ and $(0<1-\nu<1)$, respectively. We assume that marginal products are positively diminishing and all factors are complement in the production function. Moreover, public expenditure raises public input, that is, production increases with the government's goods and services in country $(i)$ based on parameter $(z)$. We assume that capital income tax levied on households includes all corporate taxes. Thus, the representative firm's production function in country $(i)$ has the following form:

$$
Y_{i, t}=F_{i}\left(K_{i i, t}+K_{j i, t}, L_{i}\right)=A_{i, t}\left(K_{i, t}^{d}\right)^{\nu}\left(L_{i}\right)^{1-\nu} G_{i, t}^{z}
$$

Where for country $(i)$ in period $(t),\left(A_{i, t}\right)$ is the technology or productivity shock common to all firms in the country and $\left(Y_{i, t}\right)$ is the real economic activity.

This representative firm maximizes its nominal profit as follows:

$$
\Pi_{i, t}=P_{i, t} Y_{i, t}-R_{t} K_{i, t}^{d}-W_{i, t} L_{i}
$$

Production factors are paid at their marginal products, and we suppose constant returns. Thus, profit maximization in Equation (13) implies the following:

$$
\begin{aligned}
& P_{i, t} \frac{\partial Y_{i, t}}{\partial K_{. i, t}^{d}}=\nu A_{i, t} P_{i, t}\left(K_{. i, t}^{d}\right)^{-(1-\nu)}\left(L_{i}\right)^{1-\nu} G_{i, t}^{z}=R_{t}>0 \\
& P_{i, t} \frac{\partial Y_{i, t}}{\partial L_{i}}=(1-\nu) A_{i, t} P_{i, t}\left(K_{. i, t}^{d}\right)^{\nu}\left(L_{i}\right)^{-\nu} G_{i, t}^{z}=W_{i, t}>0
\end{aligned}
$$

Therefore, by combining Equations (14) and (15), we obtain the following relation between the nominal wage and interest rate in country $(i)$ :

$$
W_{i, t}=\frac{(1-\nu) K_{. i, t}^{d}}{\nu L_{i}} R_{t}
$$


Moreover, households are free to invest their capital. Hence, assuming rational behavior, capital moves across borders to obtain the highest after-tax return. Then, allocation is defined according to after-tax rates of return, which are equated across countries. The profitability of a private firm, decreases by the taxation rate to pay on this profitability, must be the same across all firms in all member countries, and equal to the global real capital rate of return ( $\rho)$ and interest rate defined on the world financial market. Thus, we have the following "capital arbitrage condition":

$$
\frac{R_{t}}{P_{i, t}}\left(1-t_{i}^{k}\right)=\frac{R_{t}}{P_{j, t}}\left(1-t_{j}^{k}\right)=\rho
$$

As $\left.\left[\frac{\partial\left(\frac{R_{t}}{P_{i, t}}\right)}{\partial t_{i}^{k}}=\frac{\rho}{\left(1-t_{i}^{k}\right.}\right)^{2}>0\right]$, the required pre-tax real interest rate increases with the capital taxation rate to obtain the same after-tax real return. This equation also defines the relationship between prices in home $(i)$ and foreign country $(j)$.

Furthermore, by combining Equations (14) and (17), we obtain the following:

$$
\left(K_{i i, t}^{d}+K_{j i, t}^{d}\right)=\frac{\nu^{\frac{1}{(1-\nu)}}\left(A_{i, t}\right)^{\frac{1}{(1-\nu)}}\left(L_{i}\right) G_{i, t}^{\frac{z}{(1-\nu)}}\left(1-t_{i}^{k}\right)^{\frac{1}{(1-\nu)}}}{\rho^{\frac{1}{(1-\nu)}}}
$$

Therefore, Equation (18) implies 2 ) the following:

$$
\frac{\partial\left(K_{i i, t}+K_{j i, t}\right)}{\partial t_{i}^{k}} \frac{t_{i}^{k}}{\left(K_{i i, t}+K_{j i, t}\right)}=-\frac{t_{i}^{k}}{(1-\nu)\left(1-t_{i}^{k}\right)}<0
$$

Equation (19) is the tax elasticity of capital demand, that is, the percentage change in a given country's capital demand in response to a $1 \%$ increase in its capital tax rate, which is negative. The higher the national tax rate, the larger (more negative) is the tax elasticity. Thus, tax evasion occurs as a given country's higher taxation rate implies tax base leakage. High taxation rate impacts the tax base in an open economy, that is, capital outflow occurs if the taxation tax rate increases. A high taxation rate lowers a country's net marginal product and causes capital to relocate toward the remaining countries. A source-based capital income

2) With $\left(t_{i}^{k}=0.3\right)$ and $(\nu=0.33)$, this equation is consistent with an elasticity of $\left(\frac{\partial\left(K_{i i, t}+K_{j i, t}\right)}{\partial t_{i}^{k}} \frac{t_{i}^{k}}{\left(K_{i i, t}+K_{j i, t}\right)}\right)=-0.65$, near that mentioned in Section III E for the basic calibration of our parameters. 
tax in a small open economy also pushes up the required pre-tax rate of return, leaving the after-tax rate of return unaffected. Thus, such a process usually requires a capital stock reduction.

Furthermore, using Equations (16), (17), and (18), we obtain ${ }^{3)}$ the following:

$$
\begin{aligned}
& \frac{\partial\left(K_{j j, t}+K_{i j, t}\right)}{\partial t_{i}^{k}} \frac{t_{i}^{k}}{\left(K_{j j, t}+K_{i j, t}\right)}=0 \\
& \frac{\partial W_{i, t}}{\partial t_{i}^{k}} \frac{t_{i}^{k}}{W_{i, t}}=-\frac{\nu t_{i}^{k}}{(1-\nu)\left(1-t_{i}^{k}\right)}<0
\end{aligned}
$$

Thus, the nominal wage falls in response to high capital taxation rate in the country. Source-based capital income taxes raise the required pre-tax rate of return on capital, to ensure that the marginal post-tax rate of return is still equal to the world rate of return. As a result, such taxes tend to drive away capital and consequently depress wages or reduce employment. Therefore, the labor force bears the effective tax incidence.

Moreover, we consider a Calvo-type framework of staggered prices, where a fraction $(0<\alpha<1)$ of goods prices in each period remain unchanged, whereas prices are adjusted for the remaining fraction $(1-\alpha)$ of goods. Monopolistically competitive firms choose nominal prices to maximize profits. These profits are subject to constraints on future price adjustment frequency considering that prices may be fixed for many periods. Hence, they minimize the loss function as follows:

$$
\operatorname{Min}_{p_{i, t}^{i}} \sum_{k=0}^{\infty}(\alpha \beta)^{k} E_{t}\left(p_{i, t}^{r}-\widetilde{p_{i, t+k}^{r}}\right)^{2}
$$

Where $\left(\widetilde{p_{i, t}^{r}}\right)$ is the logarithm of the optimal price that a firm in country $(i)$ will set in period $(t)$ if price rigidity does not exist.

The firm minimizes expected losses for all future periods $(t+k)$ because it cannot set a frictionless optimal price in this period $(t+k)$. These losses are subject to the actualization rate $(\beta)$ as closer profits are given a higher weight than more distant ones. In addition, the probability that price $\left(p_{i, t}\right)$ will be fixed for $(k)$ periods until period $(t+k)$ is $\left(\alpha^{k}\right)$. Thus, by deriving according to the reset price $\left(p_{i, t}^{r}\right)$, we have the following:

3) $W_{i, t}=\frac{(1-\nu) \nu^{\frac{\nu}{(1-\nu)}} P_{i, t}\left(A_{i, t}\right)^{\frac{1}{(1-\nu)}} G_{i, t}^{\frac{z}{(1-\nu)}}\left(1-t_{i}^{k}\right)^{\frac{\nu}{(1-\nu)}}}{\rho^{\frac{\nu}{(1-\nu)}}}$. 


$$
p_{i, t}^{r}=(1-\alpha \beta) \sum_{k=0}^{\infty}(\alpha \beta)^{k} E_{t}\left(\widetilde{p_{i, t+k}^{r}}\right)
$$

Therefore, the representative firm in country $(i)$ sets the optimal reset price $\left(p_{i, t}^{r}\right)$ to the weighted average level of prices that it would have expected to reset in the future if price rigidities do not exist. As its optimal strategy, this firm fixes prices at marginal costs $\left(\widetilde{p_{i, t}^{r}}=m c_{i, t}\right)$, where $\left(m c_{i, t}\right)$ is the firm's nominal marginal production cost. Furthermore, prices in period $(t)$ are an average of past and reset prices:

$$
p_{i, t}=\alpha p_{i, t-1}+(1-\alpha) p_{i, t}^{r}
$$

Thus, by combining Equations (23) and (24)4), we obtain the following equation on inflation for producer prices in country $(i)$ :

$$
\pi_{i, t}=\beta E_{t}\left(\pi_{i, t+1}\right)+\frac{(1-\alpha)(1-\alpha \beta)}{\alpha}\left(m c_{i, t}-p_{i, t}\right)
$$

Inflation depends on expected future inflation and on the gap between frictionless optimal and current price levels, that is, on the real marginal cost. Therefore, firms' increased reset prices can cause inflationary pressures.

Equation (12) gives nominal production costs $\left(W_{i, t} L_{i}\right)$ and $\left(R_{t} K_{. i, t}^{d}\right)$ for the production of the quantity $\left(Y_{i, t}\right)$ for a firm in country $(i)$. Thus, using Equations (12), (14), and (15), the nominal marginal production cost of quantity $\left(Y_{i, t}\right)$ is as follows:

$$
M C_{i, t}=\frac{\partial\left(W_{i, t} L_{i}\right)}{\partial Y_{i, t}}=\frac{\partial\left(R_{t} K_{., t}^{d}\right)}{\partial Y_{i, t}}=\frac{R_{t}^{\nu} W_{i, t}^{1-\nu}}{\nu^{\nu}(1-\nu)^{1-\nu} A_{i, t} G_{i, t}^{z}}
$$

Thus, in logarithms and variations and using Equations (12), (17), and (26), we obtain the following variation in the real marginal production $\left.\operatorname{cost}^{5}\right)$ :

$$
\left(m c_{i, t}-p_{i, t}\right)=(1-\nu)\left(w_{i, t}-p_{i, t}\right)+\nu\left(r_{t}-p_{i, t}\right)-a_{i, t}-z g_{i, t}=0
$$

4) $p_{i, t}^{r} \frac{=1}{(1-\alpha)} p_{i, t}-\frac{\alpha}{(1-\alpha)} p_{i, t-1}=\alpha \beta E_{t}\left(p_{i, t+1}^{r}\right)+(1-\alpha \beta) \widetilde{p_{i, t}^{r}}=\frac{\alpha \beta}{(1-\alpha)} E_{t}\left(p_{i, t+1}\right)+(1-\alpha \beta) p_{i, t}^{r}-\frac{\alpha^{2} \beta}{(1-\alpha)} p_{i, t}$.

5) Equations (12), (14), (15), and (17) imply $\nu=\frac{R_{t} K_{. i, t}^{d}}{P_{i, t} Y_{i, t}}=\frac{\rho}{\left(1-t_{i}^{k}\right)} \frac{K_{. i, t}^{d}}{Y_{i, t}}$ and $(1-\nu)=\frac{W_{i, t} L_{i}}{P_{i, t} Y_{i, t}}$.

Eq. (12) implies $y_{i, t}=a_{i, t}+\nu k_{. i, t}^{d}+z g_{i, t} ; k_{. i, t}^{d}=y_{i, t} ; w_{i, t}=p_{i, t}+y_{i, t}$ (see above) and $r_{t}=p_{i, t}=p_{j, t}(17)$. 
Therefore, according to Equations (25) and (27), the Phillips curve of our DSGE model can be reduced to the following expression:

$$
\pi_{i, t}=\beta E_{t}\left(\pi_{i, t+1}\right)
$$

Then, the current inflation rate only depends on the anticipated future inflation rate.

\section{Budgetary and monetary policies}

Budgetary authorities fix national public expenditure and tax rates. For simplicity, we suppose that all government debt is held domestically and is risk-free real debt (not state-contingent). The government is supposed to credibly commit to repay public debt, taxation rates are time-invariant. The budgetary constraint of country (i)'s government is as follows:

$$
B_{i, t}=\left(1+R_{t-1}\right) B_{i, t-1}+P_{i, t} G_{i, t}-t_{i}^{c} P_{i, t} C_{i, t}-t_{i}^{l} W_{i, t} L_{i}-t_{i}^{k}\left(R_{t}-\delta P_{i, t}\right)\left(K_{i i, t}+K_{j i, t}\right)
$$

The public debt of country $(i)$ in period $(t)$ equals the public debt in the former period $(t-1)$ increased by the former public debt's interest rate, plus the current period's public expenditure to be financed, decreased by the current period's fiscal resources. In a source-based taxation system, these fiscal resources include consumption and labor taxation and capital taxation on national and foreign capital invested in the country, considering that physical capital depreciation is exempted from taxation.

In real terms and in proportion to nominal GDP $\left(Y_{i, t}\right)$, we use Equations (17) and (29) and the respective shares of production factors in footnote 6 and obtain the following:

$$
\left(\frac{B_{i, t}}{P_{i, t} Y_{i, t}}\right)=\frac{\left(1+R_{t-1}\right)}{\left(1+\pi_{i, t}\right)\left(1+y_{i, t}\right)}\left(\frac{B_{i, t-1}}{P_{i, t-1} Y_{i, t-1}}\right)+\frac{\left(G_{i, t}-t_{i}^{c} C_{i, t}\right)}{Y_{i, t}}-(1-\nu) t_{i}^{l}-\frac{\nu\left(\rho-\delta+\delta t_{i}^{k}\right) t_{i}^{k}}{\rho}
$$

Solving Equation (30) forward, with $\lim _{t \rightarrow \infty} B_{i, t}=0$ (we suppose a no-Ponzi-game and satisfaction of the intertemporal budgetary constraint), we obtain6) the following:

$$
\left(\frac{B_{i, t}}{P_{i, t} Y_{i, t}}\right)=\beta E_{t}\left\{\sum_{n=0}^{\infty} \beta^{n} \frac{\left(1+y_{i, t+n+1}\right) \cdots\left(1+y_{i, t+1}\right) C_{i, t}}{C_{i, t+n+1}}\left[(1-\nu) t_{i}^{l}+\frac{\nu\left(\rho-\delta+\delta t_{i}^{k}\right) t_{i}^{k}}{\rho}-\frac{G_{i, t+n+1}}{Y_{i, t+n+1}}+t_{i}^{c} \frac{C_{i, t+n+1}}{Y_{i, t+n+1}}\right]\right\}
$$

6) Equations (5) implies $\frac{E_{t}\left[\left(1+\pi_{i, t+n+1}\right) \cdots\left(1+\pi_{i, t+1}\right)\right]}{E_{t}\left[\left(1+R_{t+n}\right) \cdots\left(1+R_{t}\right)\right]}=\frac{\beta^{n+1} C_{i, t}}{E_{t}\left(C_{i, t+n+1}\right)}$. 
We suppose that private consumption increases in the long run at the same pace as GDP (see Equation [A7]). Therefore, using Equations (A7) and (A10) in Appendix A, the steady state long-run value of real debt-GDP ratio in country $(i)$ is as follows 7 ):

$$
\left(\frac{B_{i}}{P_{i} Y_{i}}\right)=\frac{\beta}{(1-\beta)}\left[(1-\nu) t_{i}^{l}+\frac{\nu\left(\rho-\delta+\delta t_{i}^{k}\right)}{\rho} t_{i}^{k}-\frac{G_{i}}{Y_{i}}+t_{i}^{c} \frac{C_{i}}{Y_{i}}\right]=0
$$

Appendix A details the expressions of the short-run and long-run values of all components of global demand in our macro-economic model.

Moreover, if we log-linearize Equation (30) when $\left(\pi_{i, t}\right),\left(y_{i, t}\right)$, and $\left(R_{t}\right)$ are small and use Equation (8), in terms of variations, we obtain the following:

$$
\widehat{b_{i, t}}=\left(1+R-\pi_{i}-y_{i}\right) \widehat{b_{i, t-1}}+\left(R_{t-1}-\pi_{i, t}-y_{i, t}\right)+\frac{P_{i}\left(G_{i}-t_{i}^{c} C_{i}\right)}{B_{i}}\left(c_{i, t}-y_{i, t}\right)
$$

$\left(\widehat{b_{i, t}}\right)$ is deviation of real debt to GDP $\left(\frac{B_{i, t}}{P_{i, t} Y_{i, t}}\right)$ in comparison with its last period's value.

Therefore, as $\left(G_{i}>t_{i}^{c} C_{i}\right)$ for plausible our parameter values (see Appendix A; private consumption is not the only fiscal base), we must have $\left(c_{i, t}=y_{i, t}\right)$ to avoid an outbidding of public indebtedness level.

Regarding the common central bank's monetary policy, we suppose that the nominal interest rate reacts to inflation and economic activity deviations according to a simple Taylor rule. However, central banks' activity in the world market is limited by a high degree of interest rate smoothing as interest rate variations are empirically always moderate ( $h$ is significantly high). Thus, the nominal interest rate is fixed as follows:

$$
R_{T}=h R_{T-1}+(1-h)\left[R+0.5\left(\pi_{T}-\pi^{o p t}\right)+0.5\left(y_{T}-y^{o p t}\right)\right]
$$

Where $(R)$ is the equilibrium or natural interest rate that corresponds to the long-term rate of return if prices and wages were completely flexible and $\left(\pi^{o p t}\right)$ is the targeted inflation rate. Thus, we can estimate that it fits natural economic growth in the monetary union $\left(R=y^{o p t}\right)$.

Therefore, Equation (34) implies the following common nominal interest rate:

$$
R_{T}=0.5(1-h)\left[\omega_{i} \pi_{i, T}+\left(1-\omega_{i}\right) \pi_{j, T}+\omega_{i} y_{i, T}+\left(1-\omega_{i}\right) y_{j, T}\right]+h R_{T-1}+0.5(1-h) R-0.5(1-h) \pi^{o p t}
$$

7) According to Equations (A7) and (A10) in Appendix A, $\left(\frac{G_{i}}{Y_{i}}-t_{i}^{c} \frac{C_{i}}{Y_{i}}\right)=\frac{\left[\rho(1-\nu) t_{i}^{l}+\left(\rho-\delta+\delta t_{i}^{k}\right) \nu t_{i}^{k}\right]}{\rho}$. 
Where $\left(\omega_{i}\right)$ is the relative share of country $(i)$ in the monetary union.

\section{Long-term economic growth}

We will derive the equilibrium on the goods market regarding global demand. Clearing the goods market, equality between supply and demand of goods and services in country $(i)$ during period $(T)$ requires the following:

$$
Y_{i, T}=C_{i, T}+G_{i, T}+\left(I N V_{i i, T}+I N V_{j i, T}\right)+X_{i, T}
$$

Where $\left(X_{i}\right)$ is the net exports of country $(i)$.

Thus, by combining Equations (3), (10), (12), (16), (17), (18), (29), and (36), we obtain the following (see Equation [A6] in Appendix A):

$$
X_{i, T}=\frac{\delta\left(1-t_{i}^{k}\right)}{\left(t_{j}^{k}-t_{i}^{k}\right)}\left(K_{i i, T}+K_{j i, T}\right)+\frac{\delta\left(1-t_{j}^{k}\right)}{\left(t_{j}^{k}-t_{i}^{k}\right)}\left(K_{j j, T}+K_{i j, T}\right)
$$

Therefore, the global equilibrium and Equation (37) allow to define country (i)'s commercial balance. If the capital taxation rate is weaker than in the rest of the monetary union $\left(t_{i}^{k}<t_{j}^{k}\right)$, then country $(i)$ is a net exporter of goods and services, whereas if its capital taxation rate is higher, then country $(i)$ is a net importer.

Furthermore, in logarithms and variations, Equation (36) implies the following:

$$
y_{i, T}=\frac{C_{i}}{Y_{i}} c_{i, T}+\frac{G_{i}}{Y_{i}} g_{i, T}+\frac{\left(I N V_{i i}+I N V_{j i}\right)}{Y_{i}} i n v_{. i, T}+\frac{X_{i}}{Y_{i}} x_{i, T}
$$

Where the relative shares of global demand components are mentioned in Appendix A.

Capital investment share $(\delta)$ and footnote 6 imply the following constant relative investment share in GDP:

$$
\frac{\left(I N V_{i i, T}+I N V_{j i, T}\right)}{Y_{i, T}}=\frac{I N V_{i, T}}{K_{i, T}} \frac{K_{i, T}}{Y_{i, T}}=\frac{\delta \nu\left(1-t_{i}^{k}\right)}{\rho}
$$

Thus, using Equations (33) and (38), we obtain the following:

$$
\operatorname{inv}_{. i, T}=y_{i, T}=k_{. i, T}=c_{i, T}=g_{i, T}=x_{i, T}
$$


Therefore, all economic variables and global demand factors are growing at the same pace to avoid an outbidding of public indebtedness level and allow a stable dynamic economic growth. Economic activity increases at the exogenous pace of capital accumulation in a given economy. Furthermore, according to Equations (11) and (40), this economic growth of global demand is perfectly anticipated as follows:

$$
E_{t}\left(k_{i, t+1}\right)=k_{i, t}
$$

In this context, we obtain the following based on Equations (6), (28), and (40):

$$
R_{T}=E_{T}\left(\pi_{i, T+1}\right)=\frac{1}{\beta} \pi_{i, T}=\frac{1}{\beta} \pi_{j, T}
$$

Therefore, the optimal nominal interest rate should increase in proportion to inflation rates, which should be equal in all member countries of the monetary union.

In addition, the average inflation rate $\left(\pi=\pi^{o p t}\right)$ and economic growth $\left(y=y^{o p t}\right)$ are at their optimal levels in the long run based on Equation (34). Thus, Equations (35) and (42) also imply the current nominal interest rate as follows:

$$
R_{T}=\frac{h}{[1-0.5(1-h) \beta]} R_{T-1}+\frac{0.5(1-h)(1-\beta)}{\beta[1-0.5(1-h) \beta]} \pi^{o p t}+\frac{0.5(1-h)}{[1-0.5(1-h) \beta]}\left[\omega_{i} y_{i, T}+\left(1-\omega_{i}\right) y_{j, T}\right]
$$

Therefore, the current nominal interest rate is an increasing function of its previous level (interest rate smoothing). Furthermore, it also increases with the optimal targeted inflation rate and the monetary union's economic growth.

Finally, solving Equation (33) with Equation (42) and $\left(y=y^{o p t}=R\right)$, we obtain the following variation of real public debt-GDP ratio in country $(i)$ :

$$
\widehat{b_{i, t}}=\sum_{k=0}^{\infty} \frac{1}{\left(1+R-\pi_{i}-y_{i}\right)^{k+1}} E_{t}\left(y_{i, T+k+1}-R_{T+k}+\pi_{i, T+k+1}\right)=\sum_{k=0}^{\infty} \frac{\beta}{\left[\beta\left(1-y_{i}\right)+(1-\beta) \pi_{i}\right]^{k+1}} E_{t}\left(y_{i, T+k+1}\right)
$$

Therefore, real public debt-GDP ratio is growing in proportion to future anticipated real economic activity growth rates.

\section{E. Parameter calibration}

In this section, we limit to the calibration of main parameters that intervene in our discussion of the impact of public indebtedness level on tax competition, without calibrating all parameters. 
Sorensen's (2001) EUTAX model calibrates capital share in GDP at $(\nu=0.33)$, whereas Mendoza (2001) and Mendoza and Tesar (2005) calibrate this capital share at $(\nu=0.36)$. Thus, we can calibrate capital share in GDP at $(\nu=0.33)$ consistent with empirical data and economic studies. Similarly, according to empirical data, the world after-tax net return on capital can be calibrated at $(\rho=12 \%)$. Mendoza and Tesar (2005) calibrate the depreciation rate of capital at $(\delta=0.02)$. We will retain a value close to that mentioned in most economic studies, that is, $(\delta=0.025)$.

Furthermore, De Mooij and Ederveen (2003) provide a meta-analysis to analyze the differentials in results obtained by economic surveys on investment sensibility to capital tax rates. With a large data base, they conclude that capital flows to tax havens and by nonmanufacturing firms (which may contain high financial capital) are probably more responsive to taxes than real capital, or mergers and acquisitions. The authors find large differentials in the results of the economic surveys. However, the mean value of tax rate elasticity in the literature is approximately $-0.7 \%$, that is, a $1 \%$ reduction of the host country's tax rate raises its foreign direct investment by approximately $0.7 \%$. Hines (1999) also emphasizes that fiscal context influences investment location. He finds an elasticity of $(-0.6 \%)$ and assumes that a $1 \mathrm{pp}$ increase in foreign tax rate reduces US investment in a country by $0.6 \%$.

Finally, consistent with implicit tax rates mentioned by the European Commission (2018), we will consider the following average tax rates on capital $\left(t_{i}^{k}=0.3\right)$, labor $\left(t_{i}^{l}=0.35\right)$, and consumption $\left(t_{i}^{c}=0.2\right)$.

\section{Theoretical Factors Influencing Public Debt Level}

Based on the previous theoretical model, we can now define the economic and fiscal factors that influence public debt level in a monetary union's member country (see Appendix B). We suppose that the monetary union's member countries have no fiscal coordination as in the framework of EMU, the coordination is empirically limited.

\section{A. Economic factors}

Based on Equation (B2) in Appendix B, if country (i)'s capitalization increases in period $(t)$ compared with its previous value in period $(t-1)\left(K_{i, t}>K_{., i t-1}\right)$, economic growth also increases in country $(i)$, which is the denominator of public debt-GDP ratio. Therefore, this ratio reduces. The weight of the former public debt reimbursement can be lightened. High expected capitalization and anticipated economic growth also reduce the weight of current public debt, when households' preference for public good consumption is sufficiently strong $\left(\alpha_{g}>\alpha_{c} t_{i}^{c}\right)$. Thus, we obtain the following based on Equations (B3) and (B4) in Appendix B: 


$$
\begin{gathered}
\frac{\partial\left(\frac{B_{i, T}}{P_{i, T} Y_{i, T}}\right)}{\partial\left[\frac{E_{T}\left(K_{i h, T+1}\right)-K_{i h, T}}{\left(K_{i i, T}+K_{j i, T}\right)}\right]}=-\frac{\nu\left(\alpha_{g}-\alpha_{c} t_{i}^{c}\right)\left(1-t_{h}^{k}\right)}{\rho\left(\alpha_{c}+\alpha_{g}\right)} \quad h=i \text { or } j \\
\frac{\partial\left(\frac{B_{i, T}}{P_{i, T} Y_{i, T}}\right)}{\partial\left(\frac{K_{i h, T}}{K_{i i, T}+K_{j i, T}}\right)}=\frac{\nu\left(\alpha_{g}-\alpha_{c} t_{i}^{c}\right)\left(1-t_{h}^{k}\right)\left(\rho-2 \delta+\delta t_{h}^{k}\right)}{\rho\left(\alpha_{c}+\alpha_{g}\right)} \quad h=i \text { or } j
\end{gathered}
$$

The basic calibration of the parameters of our model shows that if $\left(\alpha_{g}=\alpha_{c}\right)$, then Equation (45) implies $\partial\left(\frac{B_{i, T}}{P_{i, T} Y_{i, T}}\right) \sim-0.33 \partial\left[\frac{E_{T}\left(K_{i h, T+1}\right)-K_{i h, T}}{\left(K_{i i, T}+K_{j i, T}\right)}\right]$.

However, based on Equation (46), this situation is different if we do not consider the variation but the absolute capital stock value in a given country of the monetary union. Thus, a high level of sparing and national or foreign investment of households living in country $(i)$ increases capital stock in the monetary union. However, it also reduces available resources to finance public expenditure. Thus, if households prefer private consumption, additional resources are expected to be devoted to private investment, whereas public debt may decrease as less public expenditure needs to be financed. On the contrary, if households have a sufficiently high public consumption preference $\left(\alpha_{g}>\alpha_{c} t_{i}^{c}\right)$, public debt-GDP ratio must increase to finance public expenditure levels desired by the population. Nevertheless, this effect would be theoretically limited, that is, based on the basic calibration of our model's parameters, if $\left(\alpha_{g}=\alpha_{c}\right)$, then Equation (46) implies $\partial\left(\frac{B_{i, T}}{P_{i, T} Y_{i, T}}\right)=0.06 \partial\left(\frac{K_{i h, T}}{K_{i i, T}+K_{j i, T}}\right)$.

Furthermore, based on Equations (B5) and (B6) in Appendix B, public debt-GDP ratio derivatives according to the world capital rate of return $(\rho)$ or capital share in the production function $(\nu)$ are not clear cut. However, if capital depreciation rate increases, then public debt-GDP ratio tends to increase. Private investment must be designed to increase the capital stock but also to replace the depreciated previous capital stock at a higher pace. Thus, less financial resources finance public expenditure, and public debt increases. Based on Equation (B7) in Appendix B, we have the following:

$$
\frac{\partial\left(\frac{B_{i, T}}{P_{i, T} Y_{i, T}}\right)}{\partial \delta} \rightarrow \frac{\nu\left(1-t_{i}^{k}\right)\left[\alpha_{c}\left(t_{i}^{k}+2 \delta t_{i}^{c}\right)+\alpha_{c} t_{i}^{k} t_{i}^{c}(1-\delta)-\alpha_{g} \delta\left(2-t_{i}^{k}\right)\right]}{\rho\left(\alpha_{c}+\alpha_{g}\right)}>0
$$

Besides, if the households' preference for public goods and services increases compared with private consumption preference, public debt-GDP ratio should also increase to finance 
a higher level of public expenditure and the public goods and services desired by the population. Therefore, Equation (B8) in Appendix B implies the following:

$$
\frac{\partial\left(\frac{B_{i, T}}{P_{i, T} Y_{i, T}}\right)}{\partial\left(\frac{\alpha_{g}}{\alpha_{c}}\right)} \rightarrow \frac{\left(1+t_{i}^{c}\right)\left(\rho-2 \nu \delta+2 \nu \delta t_{i}^{k}\right)}{\rho}\left(\frac{\alpha_{c}}{\alpha_{c}+\alpha_{g}}\right)^{2}>0
$$

According to the basic calibration of our model's parameters, if $\left(\alpha_{g}=\alpha_{c}\right)$, then Equations (47) and (48) imply: $\partial\left(\frac{B_{i, T}}{P_{i, T} Y_{i, T}}\right) \sim 0.9(\partial \delta)$ and $\partial\left(\frac{B_{i, T}}{P_{i, T} Y_{i, T}}\right) \sim 0.27 \partial\left(\frac{\alpha_{g}}{\alpha_{c}}\right)$.

\section{B. Capital tax rates}

In addition to the economic factors that influence public debt level mentioned in Section IV A, fiscal factors also influence debt-GDP ratio. First, based on Equations (B11) and (B12) in Appendix B, high capital tax rate increases fiscal resources and may reduce debt-GDP ratio. However, because of tax evasion, if capital tax rate is higher than in the other member countries of the monetary union, then the fiscal base can be shortened and public indebtedness level can increase. Thus, we obtain the following:

$$
\begin{gathered}
\frac{\partial\left(\frac{B_{i, T}}{P_{i, T} Y_{i, T}}\right)}{\partial t_{i}^{k}} \rightarrow-\frac{\nu}{\rho\left(1+\frac{\alpha_{g}}{\alpha_{c}}\right)}\left[\rho-\delta+2 \delta t_{i}^{k}+2 \delta t_{i}^{c}+\frac{\alpha_{g}}{\alpha_{c}}\left(\rho-3 \delta+2 \delta t_{i}^{k}\right)\right] \\
\frac{\partial\left(\frac{B_{i, T}}{P_{i, T} Y_{i, T}}\right)}{\partial\left(t_{i}^{k}-t_{j}^{k}\right)} \rightarrow \frac{\nu\left(\alpha_{g}-\alpha_{c} t_{i}^{c}\right)\left(\rho-3 \delta+2 \delta t_{j}^{k}\right)}{\rho\left(\alpha_{c}+\alpha_{g}\right)} \frac{K_{i j, T}}{\left(K_{i i, T}+K_{j i, T}\right)}
\end{gathered}
$$

Based on the basic calibration of our model's parameters, if $\left(\alpha_{g}=\alpha_{c}\right)$, then Equation (49) implies that, on average, a $1 \%$ increase in capital tax rate would decrease public debt-GDP ratio by approximately $(-0.25 \%)$. However, regarding the robustness of our results to the parameters' calibration, high capital tax rate increases fiscal resources and reduces public debt level at a higher rate if capital share in the production function $(v)$, world average capital return $(\rho)$, and long-term capital and consumption tax rates $\left(t_{i}^{k}\right.$ and $\left.t_{i}^{c}\right)$ are high. On the contrary, high capital tax rate would be less efficient in reducing public indebtedness level if the relative preference for public goods and services $\left(\alpha_{g} / \alpha_{c}\right)$ or capital depreciation rate $(\delta)$ is high. Furthermore, based on Equation (B11) in Appendix B, high capital tax rate would also be 
less efficient in reducing public indebtedness level if households from country (i) increase their national or foreign sparing and capital investment in the monetary union, that is, if capitalization and economic growth are higher.

Nevertheless, Equation (50) also highlights an important effect of the financial openness of a monetary union. If capital tax rate is higher in country $(i)$ than in the rest of the monetary union, fiscal evasion toward the rest of the monetary union reduces the fiscal base in country (i). Thus, it contributes to increasing public debt-GDP ratio in this country, if the preference for public goods and services is sufficiently high $\left(\alpha_{g}>\alpha_{c} t_{i}^{c}\right)$. However, this effect remains moderate and depends on households' foreign capital investment from country $(i)$ in the rest of the monetary union $\left(K_{i j, T}\right)$. Using the basic calibration of our model's parameters, we obtain $\partial\left(\frac{B_{i, T}}{P_{i, T} Y_{i, T}}\right) \sim 0.07 \frac{K_{i j, T}}{\left(K_{i i, T}+K_{j i, T}\right)} \partial\left(t_{i}^{k}-t_{j}^{k}\right)$ if $\left(\alpha_{g}=\alpha_{c}\right)$.

\section{Labor and consumption tax rates}

Increasing consumption or labor tax rates rather than capital tax rate is a more efficient economic policy to collect fiscal resources and decrease public debt level due to tax evasion. Thus, based on Equation (B9) in Appendix B, we obtain the following:

$$
\frac{\partial\left(\frac{B_{i, T}}{P_{i, T} Y_{i, T}}\right)}{\partial t_{i}^{c}}-\frac{\left(\rho-2 \nu \delta+2 \nu \delta t_{i}^{k}\right)}{\rho\left(1+\frac{\alpha_{g}}{\alpha_{c}}\right)}<0
$$

According to the basic calibration of our model's parameters, if $\left(\alpha_{g}=\alpha_{c}\right)$, then Equation (51) implies that, on average, a $1 \%$ increase in consumption tax rate would decrease public debt-GDP ratio by approximately $(-0.45 \%)$. However, regarding the sensitivity of our results to this calibration, high consumption tax rate increases fiscal resources and reduces public debt at a higher rate as the average world capital return $(\rho)$ and long-term capital tax rate $\left(t_{i}^{k}\right)$ are high. On the contrary, high consumption tax rate would be less efficient in reducing public indebtedness if capital share in the production function $(\nu)$, the relative preference for public goods and services $\left(\alpha_{g} / \alpha_{c}\right)$, or capital depreciation rate $(\delta)$ is high.

Moreover, Equation (B9) in Appendix B shows that high consumption tax rate can efficiently reduce public indebtedness level if country $(i)$ is a net capital exporter in the monetary union $\left(K_{i j, T}>K_{j i, T}\right)$. On the contrary, it would be less efficient in reducing public indebtedness if households from country $(i)$ increase their national or foreign sparing and capital investment in the monetary union $\left[E_{T}\left(K_{i h, T}+1\right)>K_{i h, T}\right]$, that is, if capitalization and economic growth 
are higher.

Furthermore, using Equation (B10) in Appendix B, we obtain the following:

$$
\frac{\partial\left(\frac{B_{i, T}}{P_{i, T} Y_{i, T}}\right)}{\partial t_{i}^{l}}=-(1-\nu)<0
$$

Thus, with the basic calibration of our model's parameters, Equation (52) implies that, on average, a $1 \%$ increase in labor tax rate would decrease public debt-GDP ratio by approximately $(-0.67 \%)$. Therefore, it would be the most efficient economic policy to reduce the weight of public indebtedness. Furthermore, high labor tax rate increases fiscal resources and would be more efficient in reducing public debt level as labor share in the production function $(1-\nu)$ is high.

\section{Empinical Results}

This section will discuss our model's theoretical results using the empirical data on EMU. This section does not include econometric regressions and cointegration tests as this paper is not an econometric study but a theoretical one. We aim to provide empirical observations regarding public debt levels and tax rates in EMU only to determine whether our theoretical model is consistent with empirical observations.

For the year 1970, we will consider data on five founding members of the EU namely, Belgium, Germany, France, Italy, and the Netherlands. We have excluded Luxembourg as certain data are missing. We will also include the three countries that joined the EU in 1973, namely, Denmark, Ireland, and the United Kingdom. Then, Greece joined the EU in 1981 and Spain and Portugal in 1986. However, the theoretical model of this paper concerns fiscal interdependencies between member countries of a monetary union that share the same interest rate. Thus, in 1999, we will consider 10 among the 11 countries in the euro area: Belgium, Germany, Ireland, Spain, France, Italy, the Netherlands, Austria, Portugal, and Finland (excluding Luxembourg). Then, other countries are integrated in the euro area: Greece (2001), Slovenia (2007), Cyprus (2008) (excluding Malta, which joined in 2008, due to missing data), Slovakia (2009), Estonia (2011), Latvia (2014), and Lithuania (2015). Therefore, the empirical part of this paper will focus on these 17 member countries of the euro area. 


\section{A. Public debt levels and capital tax rates}

Empirical data show an increasing relation between implicit capital tax rate and public debt level in the member countries of the euro area in the long run. This increasing relation is validated using a panel of 234 data on EMU member countries between 1999 and 20168). A correlation analysis in 2016 shown in Figure 1 below also supports this finding. For example, in 2016, Estonia and Lithuania had the weakest implicit capital tax rates (12\% and $12.5 \%$, respectively) and lowest public debt levels (9.4\% and $40.1 \%$ of GDP, respectively). On the contrary, France had the highest implicit capital tax rate $(52.8 \%)$ and high public debt level (96.6\% of GDP). The relative share of capital taxes in total taxation also shows the empirically increasing relation between capital tax rates and public debt levels. For example, Estonia's (7.6\%) share of capital taxes in total taxation was low in 2016, where public debt level was also low (9.4\% of GDP). On the contrary, this share was significantly high in Italy $(24.3 \%)$, Portugal (21.3\%), and Greece (22.5\%), where public debt levels are the highest at $132 \%, 129.9 \%$, and $180.8 \%$ of GDP, respectively.

Figure 1. Capital tax rates and public debt levels in the euro area
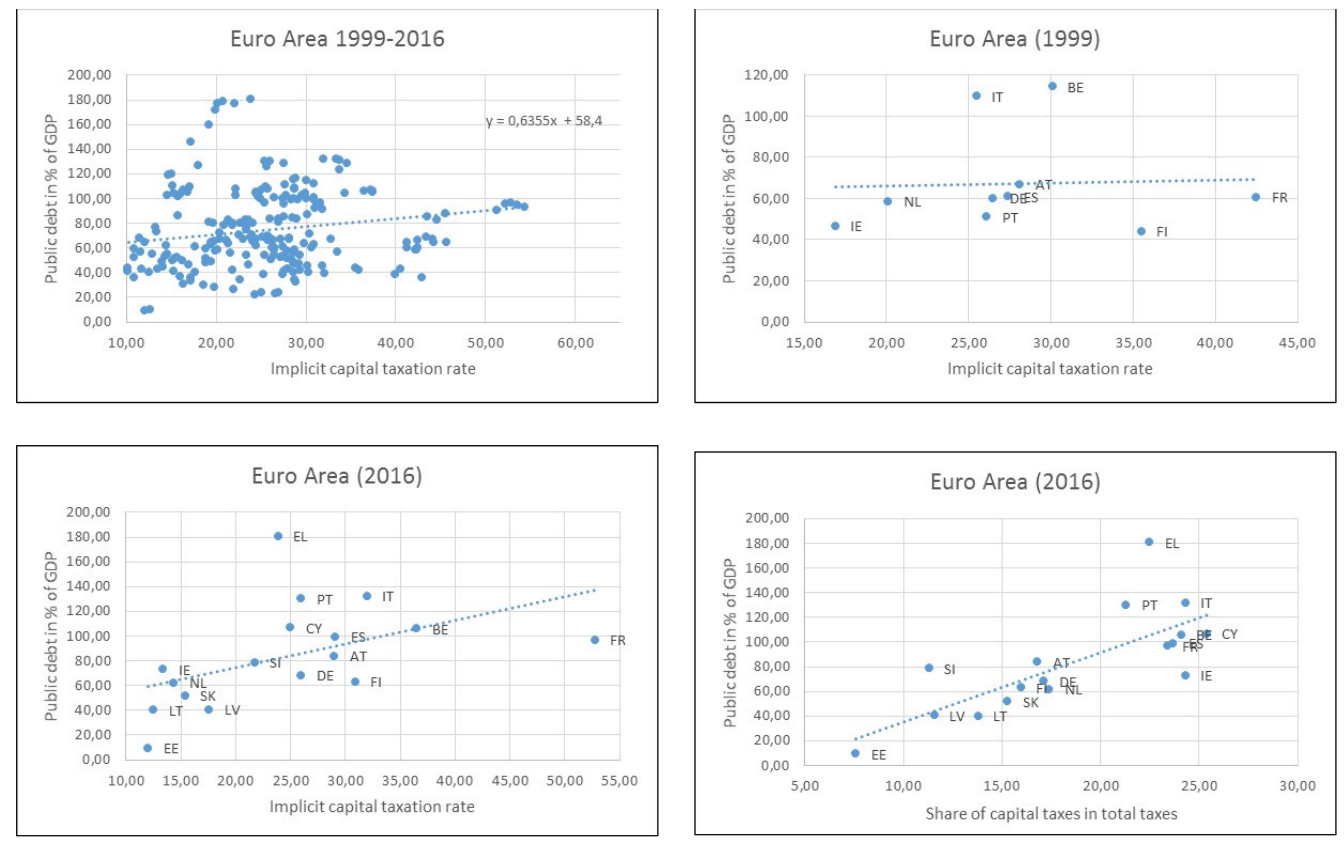

(Source) Eurostat and the European Commission

8) Data cover the period 1999-2016 for Belgium, Germany, Ireland, Spain, France, Italy, the Netherlands, Austria, Portugal, and Finland; 2001-2016 for Greece; 2007-2016 for Slovenia; 2008-2016 for Cyprus; 2009-2016 for Slovakia; 2011-2016 for Estonia; 2014-2016 for Latvia; and 2015-2016 for Lithuania. 
Therefore, the empirical data in Figure 1 show that high capital taxation policy cannot sufficiently collect additional fiscal resources and decrease public debt level. Only the less indebted European countries can afford to have low capital tax rates. Nevertheless, high capital taxation rates do not address highly indebted countries' fiscal difficulties and excessive public indebtedness. Thus, our theoretical model holds that maintaining high capital tax rates inefficiently collects fiscal resources, particularly in the context of tax competition.

Furthermore, historical data on the global euro area show that the relationship between capital tax rates and public debt levels is unclear. Average public debt level significantly increased in the euro area after the financial crisis, from $65 \%$ in 2007 to $91.9 \%$ in 2014 . However, during the same period, implicit capital tax rate decreased from $30.8 \%$ in 2007 to $27.2 \%$ in 2010 before beginning to increase again (see Figure 2). Furthermore, the average capital tax share in the euro area's total taxation varied between $19 \%$ and $23 \%$ since 1995 . However, it does not clearly relate to the global public debt level.

Figure 2. Average public debt level and capital taxation in the euro area

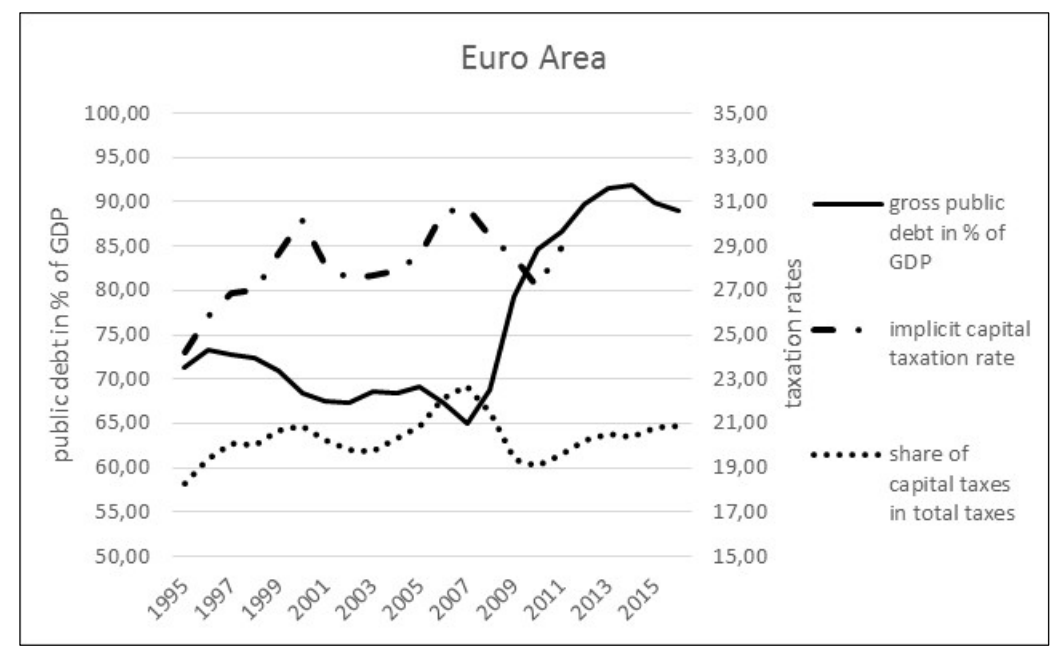

What was the historical evolution of average public debt level and capital taxation in specific member countries of the euro area? Germany's share of public debt level in GDP increased from $20 \%$ in 1970 to $80.9 \%$ in 2010 . We can observe that implicit capital tax rate strongly decreased from $47.4 \%$ in 1980 to $20 \%$ in 2010 due to the reunification. However, between 1995 and 2016, it has stabilized between $20 \%$ and $25 \%$ despite public indebtedness variations (see Appendix C). Spain's implicit capital tax rate increased from $20.7 \%$ to $42.9 \%$ between 1995 and 2007, whereas public debt level's GDP share decreased from 65.6\% in 1996 to 35.6\% in 2007. On the contrary, implicit capital tax rate decreased from $42.9 \%$ in 2007 to $25.8 \%$ in 2011, whereas public debt level's GDP share increased from $35.6 \%$ in 2007 to $100.4 \%$ 
in 2014. Therefore, the hypothesis of a decreasing relation is validated. Similarly, Belgium's implicit capital tax rate decreased from $34.1 \%$ to $24 \%$ between 1979 and 1992 , whereas public debt level's GDP share strongly increased from $57.9 \%$ in 1973 to $134.4 \%$ in 1993 . On the contrary, implicit capital tax rate increased from $24 \%$ in 1992 to $31.9 \%$ in 2006 , whereas the public debt level's GDP share decreased from $134.4 \%$ in 1993 to $87 \%$ in 2007 . However, since 2007, the relation is much more ambiguous.

Nevertheless, in France, the decreasing relation can be observed only between capital tax rate and public indebtedness level between 1982 and 1995. Implicit capital tax rate during this period decreased from $45.8 \%$ to $36.5 \%$, whereas public debt level's GDP share increased from $25.5 \%$ to $55.8 \%$. However, since 1995 , the relation is mainly increasing between both economic variables. Our theoretical model shows that this could be explained by France's excessive capital taxation rate compared with its counterparts in the monetary union. Therefore, France's average implicit capital tax rate increased from $36.5 \%$ in 1995 to $52.8 \%$ in 2016 , which was significantly higher than the euro area's average capital tax rate (approximately 29\%). Therefore, this excessive capital tax rate could help explain France's increase in public debt level's GDP share from 55.8\% in 1995 to $96.6 \%$ in 2016.

In Italy, capital tax rate and public debt level increases since the 1970s are highly correlated, whereas in the Netherlands, empirical data show an ambiguous relation. To sum up, our theoretical model shows that capital taxation cannot efficiently collect additional fiscal resources and decrease public debt level in the context of a monetary union.

\section{B. Public debt levels and labor tax rates}

Our theoretical model shows that only a country can afford high public indebtedness level (decreasing relation) when its labor tax rate is weak. Do empirical data validate this result?

The euro area's average public debt level increased since the 1970s. Thus, implicit labor tax rate in the EU slightly increased from approximately $30 \%$ in 1973 to $38.4 \%$ in 2016 to collect sufficient fiscal resources for financing the public debt (see Figure 3). However, since 1995, implicit labor tax rate is significantly stable (approximately 40\%) in the euro area's member countries. This condition persisted despite the continuous growth of public indebtedness, which always necessitates considerable fiscal resources. In addition, labor taxes' average share in total taxation was approximately $55 \%$ in the EU before 1995 , whereas it has been limited to approximately $50 \%$ after 1995 in the euro area. Therefore, this finding could be consistent with the fact that high public debt levels in a monetary union can only be sustained in countries where labor tax rates are restricted. 
Figure 3. Average public debt level and labor taxation in the euro area

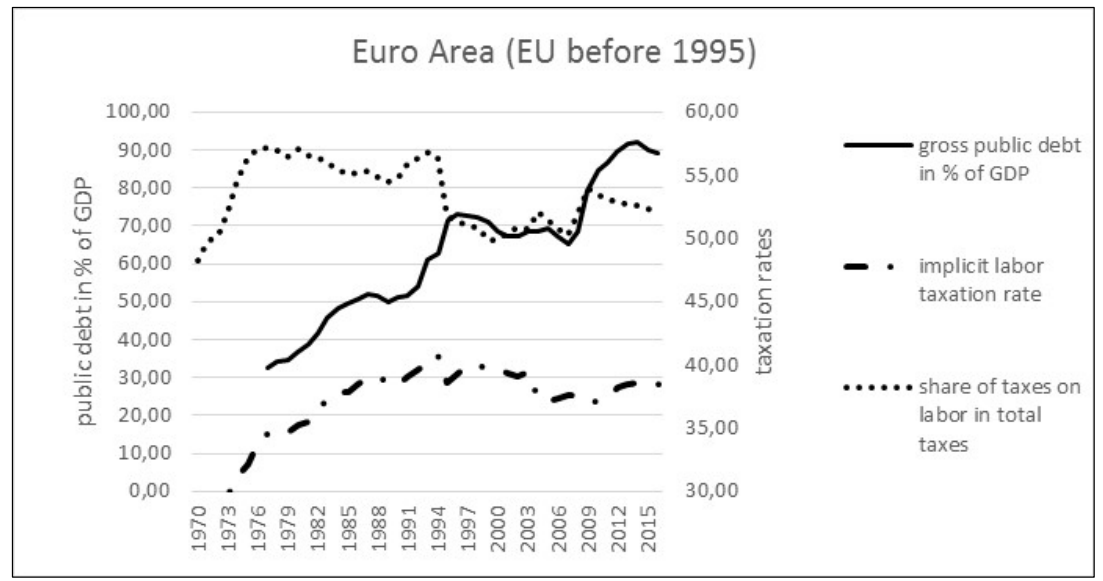

An examination of the historical data of specific European countries (see Appendix C) shows the following results. Germany's public debt's GDP share increased from 38.9\% in 1991 to $80.9 \%$ in 2010 . Implicit labor tax rate slightly decreased from $39.8 \%$ to $36.9 \%$ between 1991 and 2010, whereas the labor taxes' share in total taxation decreased from $65 \%$ to $55 \%$ during the same period. France's public debt level's GDP share increased from $20 \%$ in 1980 to $96.6 \%$ in 2016. Then, implicit labor tax rate reduced from $44.1 \%$ in 1994 to $38.5 \%$ in 2010 , whereas labor taxes' share in total taxation decreased from $56.7 \%$ to $52.8 \%$.

Italy and Belgium's public debt significantly increased. Thus, implicit labor tax rate has also increased in the 1970 s and 1980 s to finance this public debt. However, implicit labor tax rate stabilized at approximately $43 \%$ in Italy and Belgium since the 1990s. Spain's public debt level's GDP share significantly increased from $24.5 \%$ in 1982 to $100.4 \%$ in 2014 . Notwithstanding, implicit labor tax rate significantly remains stable at approximately $30 \%$ since the 1980s. Lastly, in the Netherlands, this rate stabilized at approximately $32 \%$ after a huge decrease in the tax rate from $52.3 \%$ in 1991 to $31.4 \%$ in 2000 , despite public debt level variations. Therefore, since the creation of the EMU, labor tax rate variations in the member countries are negligible and relatively independent from public debt level variations.

Furthermore, the empirical data show an increasing relationship between implicit labor tax rate and public debt level in the euro area's member countries. A panel of 234 data of EMU member countries between 1999 and 2016 and a correlation analysis at a specific date (see Figure 4) validate this increasing relationship. Thus, in 1999 (the EMU's creation), Spain and Ireland's implicit labor tax rates and public debt levels' GDP share were weak at $28.1 \%$ and $28.5 \%$ and $60.9 \%$ and $46.6 \%$, respectively. Similarly, in 2016, Latvia, Lithuania, and Estonia had weak implicit labor tax rates and lowest public debt levels' GDP share at 29.8\%, 32.2\%, and $34.1 \%$ and $40.5 \%, 40.1 \%$, and $9.4 \%$, respectively. On the contrary, in 2016, Greece, Italy, 
and Belgium had high implicit labor tax rates and the highest public debt levels' GDP share at $41 \%, 42.6 \%$, and $42.4 \%$ and $180.8 \%, 132 \%$, and $105.9 \%$, respectively. Nevertheless, we can give the following interpretation to this positive link.

Weakly indebted countries alone can afford weak labor tax rates as the weight of their public debt reimbursement is limited and they need less fiscal resources. Our model shows that weak labor tax rates imply a risk of increasing public debt level. Thus, labor taxes' share in total taxation and public debt level show a decreasing relationship (see Figure 4). In 2016, Cyprus and Greece had low labor tax share in total taxation and high public debt levels' GDP share at $34.7 \%$ and $39.5 \%$ and $106.6 \%$ and $180.8 \%$, respectively. On the contrary, Austria and Germany had the highest share of labor taxes in total taxation and limited public debt levels' GDP share at $55.7 \%$ and $56.5 \%$ and $83.6 \%$ and $68.2 \%$, respectively.

Figure 4. Labor tax rates and public debt levels in the euro area
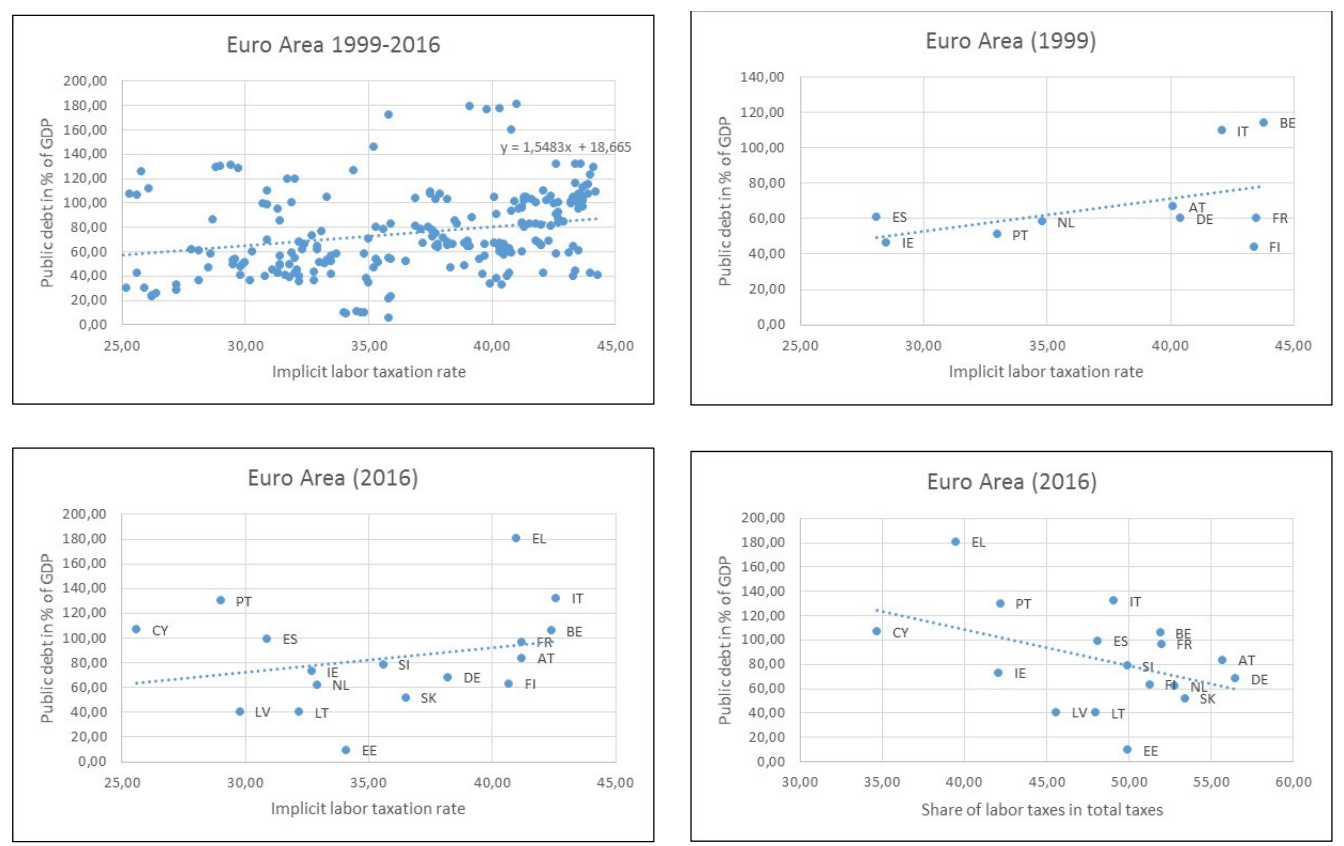

(Source) Eurostat and the European Commission

To conclude, the empirical data do not contradict our theoretical model's result. Weak labor tax rates imply risks of limiting fiscal resources and increasing public debt level. Therefore, weakly indebted countries (Latvia, Lithuania, and Estonia) could afford weak labor tax rates. On the contrary, a high share of labor taxes in total taxation could limit the public debt level in other countries, for example, Austria and Germany. These countries rigorously manage their public spending and have high labor tax rates for collecting fiscal resources. 


\section{Public debt levels and consumption tax rates}

The empirical data show a decreasing relationship between implicit consumption tax rates and public debt levels of the euro area's member countries. A panel of 234 data of the EMU member countries between 1999 and 2016 and a correlation analysis at a specific date validate this decreasing relationship (see Figure 5). Therefore, consistent with our theoretical result, a weak consumption tax rate implies the risk of high public debt. For example, in 1999, Finland had high implicit consumption tax rate (29.3\%) and low public debt level (44.1\% of GDP), whereas Italy had low implicit consumption tax rate (18\%) but high public debt level $(109.7 \%$ of GDP). Similarly, in 2016, Estonia and Finland had the highest implicit consumption tax rates but low public debt levels' GDP share at $27.7 \%$ and $27.7 \%$ and $9.4 \%$ and $63 \%$, respectively. On the contrary, Greece had moderate implicit consumption tax rate $(20.1 \%)$ but high public debt level (180.8\% of GDP). This decreasing relationship is also evident in the EU countries that are not members of the euro area. For example, in 2016, Denmark and Sweden had high implicit consumption tax rates but low public debt levels.

Figure 5. Consumption tax rates and public debt levels in the euro area
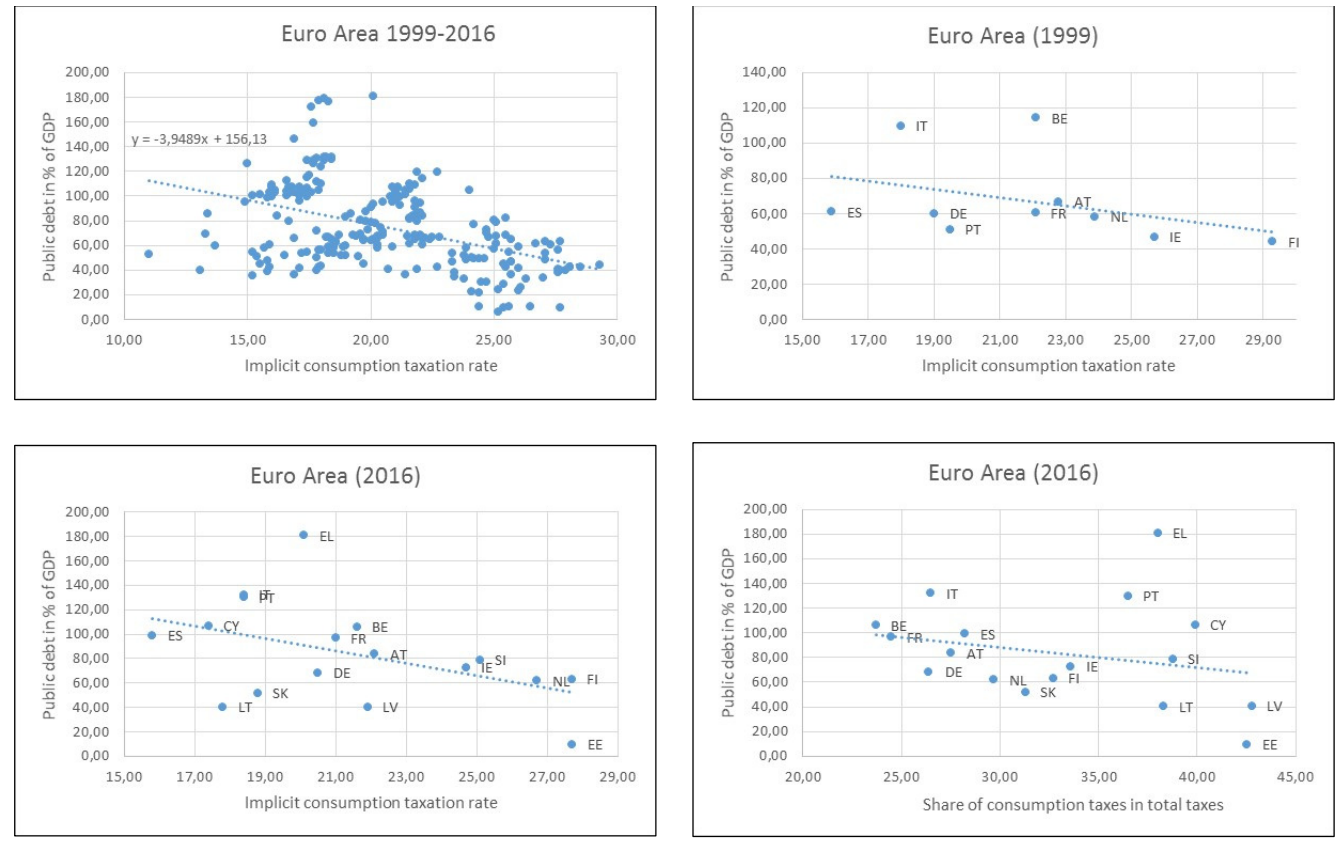

(Source) Eurostat and the European Commission

The relative share of consumption taxes in total taxation also supports this decreasing relation (see Figure 5). For example, in 2016, Belgium and Italy had low share of consumption taxes in total taxation but high public debt levels' GDP share at $23.7 \%$ and $26.5 \%$ and $105.9 \%$ 
and $132 \%$, respectively. On the contrary, Estonia, Latvia, and Lithuania had high share of consumption taxes in total taxation and low public debt levels' GDP share at $42.5 \%, 42.8 \%$, and $38.3 \%$ and $9.4 \%, 40.5 \%$, and $40.1 \%$, respectively.

Furthermore, Figure 6 shows that the EU's average public debt level increased (from 32\% in 1977 to $65.3 \%$ of GDP in 1999) as well as that of the euro area (up to $91.9 \%$ of GDP in 2014). In this context, implicit consumption tax rate increased from $16 \%$ in 1985 to $20.5 \%$ in 2016 to finance this public debt. Nevertheless, the average implicit consumption tax rate stabilized at approximately 20\% since 1999 and EMU's creation, despite increasing average public debt level. Moreover, consumption taxes' share in total taxation decreased from $32.1 \%$ in 1970 to $27 \%$ in 2016 in the euro area.

Figure 6. Average public debt level and consumption taxation in the euro area

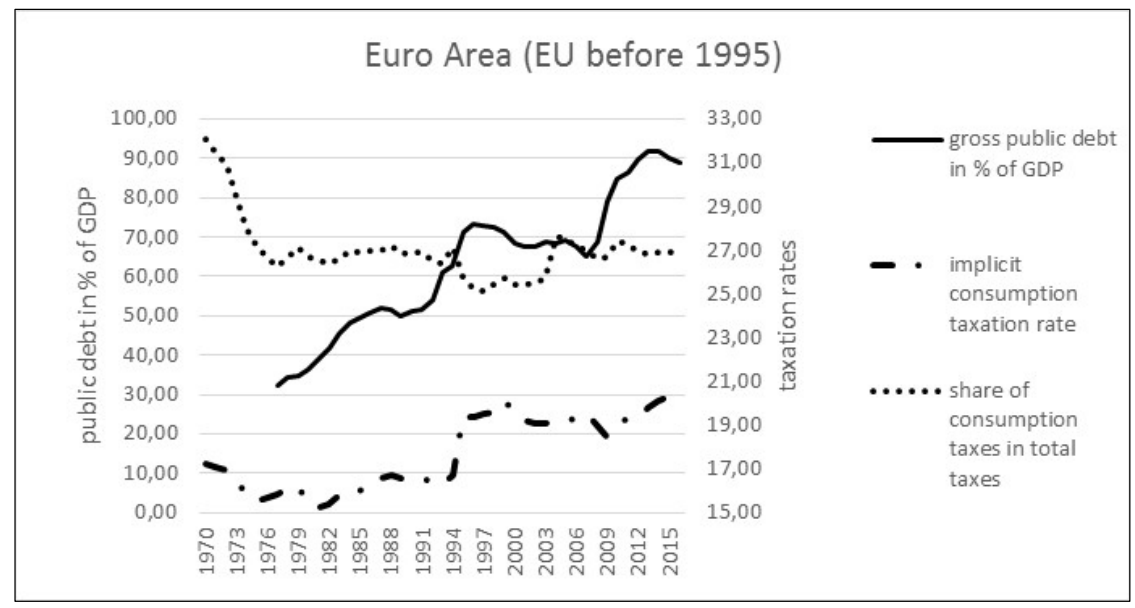

An examination of the historical data of specific European countries (see Appendix C) shows the following evolutions. Germany's public debt's GDP share increased from $17.8 \%$ in 1970 to $80.9 \%$ in 2010 . Implicit consumption tax rate also increased from $15.4 \%$ in 1984 to $18.8 \%$ in 1995 to finance this public debt. However, this rate subsequently stabilized at approximately $20 \%$, despite the increasing public debt level. In addition, consumption taxes' share in total taxation decreased from $29.8 \%$ in 1970 to approximately $24.3 \%$ in 1999 . France's public debt level's GDP share increased from $18 \%$ in 1970 to $96.6 \%$ in 2016 . However, implicit consumption tax rate stabilized at approximately $20 \%$ after 1999, despite the increasing public debt level. Moreover, consumption taxes' share in total taxation decreased from $36.5 \%$ in 1970 to $24.5 \%$ in 2016.

Italy's public debt level's GDP share increased from $35.7 \%$ in 1970 to $132 \%$ in 2016 . The country's implicit consumption tax rate stabilized at approximately $18 \%$ since 1999 , despite the increasing public debt. Moreover, consumption taxes' share in total taxation decreased from 
$38.3 \%$ in 1970 to $26.5 \%$ in 2016 . Belgium's public debt's GDP share reached a maximal level of $134.4 \%$ in 1994 . Subsequently, it reduced to $87 \%$ of GDP in 2007 , whereas implicit consumption tax rate increased from $15.8 \%$ in 1992 to $21 \%$ in 1999 , but stabilized after EMU's creation. In addition, although public debt level was increasing, consumption taxes' share in total taxes decreased from $32.9 \%$ in 1970 to $23 \%$ in 1993 . Finally, the Netherlands's public debt level's GDP share reduced from $74.2 \%$ in 1990 to $44.7 \%$ in 2006 . Similarly, implicit consumption tax rate and consumption taxes' share in total taxes increased from $17.5 \%$ to $25.4 \%$ and from $24.2 \%$ to $31.5 \%$, respectively.

Therefore, the empirical data validate the theoretical result that if consumption tax rate decreases, or at least stabilizes in a member country of a monetary union, then available fiscal resources can be limited, increasing public debt level. Relying on high consumption taxes has been often correlated with better limitation of public debt weight.

\section{Conclusion}

Our theoretical model shows that labor tax rate increase would be the most efficient economic policy to collect additional fiscal resources and reduce public debt-GDP ratio, mainly if the labor share in the production function is high. On the contrary, weak labor tax rates imply the risk of limiting fiscal resources and increasing public debt level. Therefore, the empirical data show that only initially weakly indebted countries (Latvia, Lithuania, and Estonia) can afford weak labor tax rates. On the contrary, high labor taxes' share in total taxation could contribute to limiting public debt level in other countries, for example, Austria and Germany. However, since EMU's creation, labor tax rate variations in the member countries are moderate and relatively independent from public debt level variations.

Furthermore, our model assumes that consumption tax rate increase also allows collecting additional fiscal resources, mainly if the preference for private goods compared with public goods consumption is high. On the contrary, a weak consumption taxation rate would imply the risk of higher public debt level. Thus, our empirical data show that relying on higher consumption taxes has empirically often been correlated with better limitation to public debt weight (Estonia and Finland). On the contrary, low consumption tax rates could hinder Greece and Spain's public debt level decrease.

Besides, according to our theoretical model, a fiscal policy using capital taxation would have ambiguous consequences and would be less efficient. First, high capital tax rate would be less efficient compared with other tax rate increase to broaden the fiscal base and reduce debt-GDP ratio in a monetary union's country member. It would be particularly inefficient if the capital share in the production function is weak. Furthermore, in the context of tax 
competition, if capital tax rate is higher than the average capital tax rate in the rest of the monetary union, then tax evasion toward foreign countries could deteriorate this fiscal base and increase public debt level. For example, the empirical data show that France's excessive capital tax rate compared with the rest of the euro area could have contributed to public debt level increase.

Therefore, the empirical data show an ambiguous trend between the historical evolutions of implicit capital tax rates and public debt levels of the euro area's member countries. However, relative situations of these member countries at specific dates would show that only the less indebted countries can afford low capital tax rates. The most indebted countries must maintain non-negligible capital tax rates in order to obtain sufficient fiscal resources to finance their public expenditure and high public debt reimbursement. Nevertheless, a high capital tax rate policy cannot efficiently collect fiscal resources and decrease public debt level. Highly indebted countries (France) do not address their fiscal difficulties and excessive public debt through high capital tax rates. Therefore, as our theoretical model shows, a high capital tax rate policy is inefficient in collecting fiscal resources, particularly in the context of tax competition.

Our theoretical model gives interesting results regarding the link between various tax rates and public debt levels in monetary union's member countries, which are globally consistent with empirical observations. However, this model is simplified and thus we could extend the current research by allowing time variations in tax rates. We could also consider that labor supply is not fixed but can vary according to economic agents' real wage and preferences between labor and leisure. Then, we could introduce unemployment rate in the model. We could also introduce the presence of non-Ricardian agents in rule-of-thumb consumers, who cannot optimize their consumption level but consume their disposable income. These agents' revenues are exclusively labor incomes, whose taxation could be more risky with regard to private consumption. These paths remain open for future research.

\section{References}

Arcalean, C. (2017). International tax competition and the deficit bias. Economic Inquiry, 55(1), 51-72. Arulampalam, W., Devereux, M. P., \& Maffini, G. (2012). The direct incidence of corporate income tax on wages. European Economic Review, 56(6), 1038-1054.

Azémar, C., \& Hubbard, R. G. (2015). Country characteristics and the incidence of Capital income taxation on wages: An empirical assessment. Canadian Journal of Economics, 48(5), 1762-1802.

Baldwin, R. E., \& Krugman, P. (2004). Agglomeration, integration and tax harmonization. European Economic Review, 48(1), 1-23.

Bond, S., Chennells, L., Devereux, M. P., Gammie, M., \& Troup, E. (2000). Corporate tax harmonization 
in Europe: A guide to the debate. London: Institute for Fiscal Studies.

Bretschger, L., \& Hettich, F. (2002). Globalization, Capital mobility and tax competition. Theory and evidence for OECD countries. European Journal of Political Economy, 18(4), 695-716.

Cai, H., \& Treisman, D. (2005). Does competition for Capital Discipline Governments? Decentralization, globalization, and public policy. American Economic Review, 95(3), 817-830.

De Mooij, R. A., \& Ederveen, S. (2003). Taxation and foreign direct investment: A synthesis of empirical research. International Tax and Public Finance, 10(6), 673-693.

Devereux, M. P. (2007). The impact of taxation on the location of Capital, firms and profit: A survey of empirical evidence (Working Paper No. 07/02). Oxford: Oxford University Centre for Business Taxation.

Devereux, M. P., Griffith, R., \& Klemm, A. (2002). Corporate income tax reforms and international tax competition. Economic Policy, 17(35), 449-495.

Devereux, M. P., \& Sørensen, P. B. (2006). The corporate income tax: international trends and options for fundamental reform. Brussels: European Commission, Directorate-General for Economic and Financial Affairs.

European Commission. (2000). Taxation trends in the European Union. Data for the EU member states, Iceland and Norway. Luxembourg: Publications of the European Union.

European Commission. (2005). Taxation trends in the European Union. Data for the EU member states, Iceland and Norway. Luxembourg: Publications of the European Union.

European Commission. (2018). Taxation trends in the European Union. Data for the EU member states, Iceland and Norway. Luxembourg: Publications of the European Union.

Felix, R. A. (2007). Passing the burden: Corporate tax incidence in open economies (LIS Working Paper Series, No. 468).

Garretsen, H., \& Peeters, J. (2007). Capital mobility, agglomeration and corporate tax rates: is the race to the bottom for real? CESifo Economic Studies, 53(2), 263-293.

Genschel, P. (2001). Globalization, tax competition, and the fiscal viability of the welfare state (Max-Planck Institut für Gesellschaftsforschung Working Paper, No. 01/1).

Hassett, K. A., \& Mathur, A. (2006). Taxes and Wages (American Enterprise Institute Working Paper No. 128$)$.

Haufler, A., Klemm, A., \& Schjelderup, G. (2006). Globalization and the Mix of wage and profit taxes (CESifo Working Paper, No. 1678).

Hines, J. R. (1999). Lessons from behavioral responses to international taxation. National Tax Journal, 52(2), 305-322.

Hines, J. R. (2007). Corporate Taxation and International competition. In A. J. Auerbach, J. R. Hines \& J. Slemrod (Eds.), Taxing Corporate Income in the 21st Century (pp. 268-295). Cambridge, UK: Cambridge University Press.

Janeba, E., \& Todtenhaupt, M. (2016). Fiscal competition and public debt [Zentrum für Europäische Wirtschaftsforschung GmbH], (Discussion Paper, No. 16-013).

Kind, H. J., Knarvik, K. H. M., \& Schjelderup, G. (2000). Competing for capital in a "lumpy" world. Journal of Public Economics, 78(3), 253-274. 
Krogstrup, S. (2004). Are corporate taxes racing to the bottom in the European Union? (Economic Policy Research Unit Working Paper 04-04).

Mendoza, E. G. (2001). The international macroeconomics of taxation and the case against European tax harmonization (NBER Working Paper, No. 8217).

Mendoza, E. G., \& Tesar, L. L. (2005). Why hasn't tax competition triggered a race to the bottom? Some quantitative lessons from the EU. Journal of Monetary Economics, 52(1), 163-204.

Slemrod, J. (2004). Are corporate tax rates, or countries, converging? Journal of Public Economics, 88(6), 1169-1186.

Sorensen, P. B. (2000). The case for international tax co-ordination reconsidered. Economic Policy, 15(31), 430-472.

Sorensen, P. B. (2001). Tax coordination in the European Union: What are the issues? Swedish Economic Policy Review, 8, 143-195.

Sorensen, P. B. (2003). International tax competition: A new framework for analysis. In K. Aiginger \& G. Hutschenreiter (Eds.), Economic policy Issues for the Next Decade (pp. 189-201). Boston: Springer.

Sorensen, P. B. (2006). Can capital income taxes survive? And should they? (CES-ifo Working Paper, No. 1793).

Zodrow, G. R. (2006). Capital mobility and source-based taxation of capital income in small open economies. International Tax and Public Finance, 13(2/3), 269-294. 


\section{Appendix A: Main Global Demand Components}

Using the equality between capital's demand and supply $\left(K_{\cdot, i}^{s}=K_{., i}^{d}\right)$ and Equations (3), (10), (16), and (17), we obtain the following private consumption level:

$$
\begin{aligned}
C_{i, T}= & \frac{\left[\left(1-t_{i}^{l}\right)(1-\nu) \rho+\left(1-t_{i}^{k}\right) \nu(1+\rho)-\nu \delta\left(1-t_{i}^{k}\right)\left(2-t_{i}^{k}\right)\right]}{\nu\left(1-t_{i}^{k}\right)\left(1+t_{i}^{c}\right)} K_{i i, T} \\
& +\frac{\left(1+\rho-2 \delta+\delta t_{j}^{k}\right)\left(1-t_{j}^{k}\right)}{\left(1+t_{i}^{c}\right)\left(1-t_{i}^{k}\right)} K_{i j, T}+\frac{\left(1-t_{i}^{l}\right)(1-\nu) \rho}{\nu\left(1-t_{i}^{k}\right)\left(1+t_{i}^{c}\right)} K_{j i, T}-\frac{1}{\left(1+t_{i}^{c}\right)} E_{T}\left(K_{i i, T+1}\right) \\
& -\frac{\left(1-t_{j}^{k}\right)}{\left(1+t_{i}^{c}\right)\left(1-t_{i}^{k}\right)} E_{T}\left(K_{i j, T+1}\right)-\frac{\rho}{\left(1+t_{i}^{c}\right)\left(1-t_{i}^{k}\right) R_{T}} B_{i, T}+\frac{\rho\left(1+R_{T-1}\right)}{\left(1+t_{i}^{c}\right)\left(1-t_{i}^{k}\right) R_{T}} B_{i, T-1}
\end{aligned}
$$

Equations (16), (17), (29), and (A1) imply the following:

$$
\begin{aligned}
G_{i, T}= & \frac{\left[\left(t_{i}^{c}+t_{i}^{l}\right) \rho+t_{i}^{c}\left(1-t_{i}^{k}\right) \nu+\left(t_{i}^{k}-t_{i}^{l}\right) \nu \rho-\nu \delta\left(1-t_{i}^{k}\right)\left(2 t_{i}^{c}+t_{i}^{k}\right)\right]}{\nu\left(1-t_{i}^{k}\right)\left(1+t_{i}^{c}\right)} K_{i i, T} \\
& +\frac{\left[\nu \rho t_{i}^{k}\left(1+t_{i}^{c}\right)-\nu \delta t_{i}^{k}\left(1+t_{i}^{c}\right)\left(1-t_{i}^{k}\right)+\left(t_{i}^{c}+t_{i}^{l}\right)(1-\nu) \rho\right]}{\nu\left(1-t_{i}^{k}\right)\left(1+t_{i}^{c}\right)} K_{j i, T} \\
& +\frac{t_{i}^{c}\left(1+\rho-2 \delta+\delta t_{j}^{k}\right)\left(1-t_{j}^{k}\right)}{\left(1+t_{i}^{c}\right)\left(1-t_{i}^{k}\right)} K_{i j, T}-\frac{t_{i}^{c}}{\left(1+t_{i}^{c}\right)} E_{T}\left(K_{i i, T+1}\right) \\
& -\frac{t_{i}^{c}\left(1-t_{j}^{k}\right)}{\left(1+t_{i}^{c}\right)\left(1-t_{i}^{k}\right)} E_{T}\left(K_{i j, T+1}\right)+\frac{\rho}{\left(1+t_{i}^{c}\right)\left(1-t_{i}^{k}\right) R_{T}} B_{i, T}-\frac{\rho\left(1+R_{T-1}\right)}{\left(1+t_{i}^{c}\right)\left(1-t_{i}^{k}\right) R_{T}} B_{i, T-1}
\end{aligned}
$$

Equations (12) and (18) imply the following production level:

$$
Y_{i, T}=\frac{\rho}{\nu\left(1-t_{i}^{k}\right)}\left(K_{i i, T}+K_{j i, T}\right)
$$

Thus, Equations (10), (36), (A1), (A2), and (A3) imply the following:

$$
\begin{aligned}
X_{i, T}= & Y_{i, T}-\left(C_{i, T}+G_{i, T}+I N V_{i i, T}+I N V_{j i, T}\right) \\
= & \delta\left(K_{i i, T}+K_{j i, T}\right)+\frac{\left(1-t_{j}^{k}\right)}{\left(1-t_{i}^{k}\right)}\left[E_{T}\left(K_{i j, T+1}\right)-\left(1-2 \delta+\rho+\delta t_{j}^{k}\right) K_{i j, T}\right] \\
& \quad-\left[E_{T}\left(K_{j i, T+1}\right)-\left(1-2 \delta+\rho+\delta t_{i}^{k}\right) K_{j i, T}\right]
\end{aligned}
$$


Furthermore, according to Equation (A4), $\left(X_{i, T}=-X_{j, T}\right)$ implies the following:

$$
\begin{aligned}
{\left[E_{T}\left(K_{i j, T+1}\right)-\left(1-2 \delta+\rho+\delta t_{j}^{k}\right) K_{i j, T}\right]=} & -\frac{\delta\left(1-t_{i}^{k}\right)}{\left(t_{i}^{k}-t_{j}^{k}\right)}\left(K_{i i, T}+K_{j i, T}+K_{j j, T}+K_{i j, T}\right) \\
& +\frac{\left(1-t_{i}^{k}\right)}{\left(1-t_{j}^{k}\right)}\left[E_{T}\left(K_{j i, T+1}\right)-\left(1-2 \delta+\rho+\delta t_{i}^{k}\right) K_{j i, T}\right]
\end{aligned}
$$

Therefore, by combining Equations (A4) and (A5), we obtain the following:

$$
X_{i, T}=\frac{\delta\left(1-t_{i}^{k}\right)}{\left(t_{j}^{k}-t_{i}^{k}\right)}\left(K_{i i, T}+K_{j i, T}\right)+\frac{\delta\left(1-t_{j}^{k}\right)}{\left(t_{j}^{k}-t_{i}^{k}\right)}\left(K_{j j, T}+K_{i j, T}\right)
$$

In addition, Equations (10), (32), (A1), (A2), (A3), and (A4) imply the following long-term values and relative shares of the various GDP components of global demand:

$$
\begin{aligned}
& \frac{C_{i}}{Y_{i}}=\frac{\left(1-t_{i}^{l}\right)(1-\nu)}{\left(1+t_{i}^{c}\right)}+\frac{\nu\left(1-t_{i}^{k}\right)\left(\rho-2 \delta+\delta t_{i}^{k}\right)}{\left(1+t_{i}^{c}\right) \rho}+\frac{\nu\left[\left(1-t_{j}^{k}\right)\left(\rho-2 \delta+\delta t_{j}^{k}\right) K_{i j}-\left(1-t_{i}^{k}\right)\left(\rho-2 \delta+\delta t_{i}^{k}\right) K_{j i}\right]}{\left(1+t_{i}^{c}\right) \rho\left(K_{i i}+K_{j i}\right)} \\
& \frac{X_{i}}{Y_{i}}=\frac{\nu \delta\left(1-t_{i}^{k}\right)}{\rho}-\frac{\nu\left[\left(1-t_{j}^{k}\right)\left(\rho-2 \delta+\delta t_{j}^{k}\right) K_{i j}-\left(1-t_{i}^{k}\right)\left(\rho-2 \delta+\delta t_{i}^{k}\right) K_{j i}\right]}{\rho\left(K_{i i}+K_{j i}\right)} \\
& \frac{I N V_{i i}}{Y_{i}}=\frac{\nu \delta\left(1-t_{i}^{k}\right)}{\rho}-\frac{\nu \delta\left(1-t_{i}^{k}\right)}{\rho\left(K_{i i}+K_{j i}\right)} K_{j i} \frac{I N V_{j i}}{Y_{i}}=\frac{\nu \delta\left(1-t_{i}^{k}\right)}{\rho\left(K_{i i}+K_{j i}\right)} K_{j i} \\
& \frac{G_{i}}{Y_{i}}=\frac{\left[\nu \rho\left(t_{i}^{k}-t_{i}^{l}\right)-\nu \delta\left(2 t_{i}^{c}+t_{i}^{k}\right)\left(1-t_{i}^{k}\right)+\left(t_{i}^{c}+t_{i}^{l}\right) \rho\right]}{\left(1+t_{i}^{c}\right) \rho} \\
& +\frac{\nu t_{i}^{c}\left[\left(1-t_{j}^{k}\right)\left(\rho-2 \delta+\delta t_{j}^{k}\right) K_{i j}-\left(1-t_{i}^{k}\right)\left(\rho-2 \delta+\delta t_{i}^{k}\right) K_{j i}\right]}{\left(1+t_{i}^{c}\right) \rho\left(K_{i i}+K_{j i}\right)}
\end{aligned}
$$

\section{Appendix B: Optimal Public Debt Level}

According to Equations (9), (A1), and (A2), the optimal public debt level that maximizes the representative consumer's utility function verifies $\left(\alpha_{c} G_{i, t}=\alpha_{g} C_{i, t}\right)$. Thus, we obtain the following: 


$$
\begin{aligned}
& -\frac{\left[\left(\alpha_{c}+\alpha_{g}\right) \rho\left(t_{i}^{l}-\nu t_{i}^{l}+\nu t_{i}^{k}\right)+\left(\alpha_{c} t_{i}^{c}-\alpha_{g}\right)\left(\rho+\nu-\nu t_{i}^{k}\right)\right]}{\nu\left(1-t_{i}^{k}\right)\left(1+t_{i}^{c}\right)} K_{i i, T} \\
& +\frac{\delta\left[2\left(\alpha_{c} t_{i}^{c}-\alpha_{g}\right)+\left(\alpha_{c}+\alpha_{g}\right) t_{i}^{k}\right]}{\left(1+t_{i}^{c}\right)} K_{i i, T}-\frac{\left(\alpha_{c} t_{i}^{c}-\alpha_{g}\right)\left(1+\rho-2 \delta+\delta t_{j}^{k}\right)\left(1-t_{j}^{k}\right)}{\left(1+t_{i}^{c}\right)\left(1-t_{i}^{k}\right)} K_{i j, T} \\
& +\frac{\left(\alpha_{c}+\alpha_{g}\right)\left(1-t_{i}^{l}\right)(1-\nu) \rho}{\nu\left(1-t_{i}^{k}\right)\left(1+t_{i}^{c}\right)} K_{j i, T}-\alpha_{c} \frac{\left[(1-\nu) \rho+\nu \rho t_{i}^{k}-\nu \delta t_{i}^{k}\left(1-t_{i}^{k}\right)\right]}{\nu\left(1-t_{i}^{k}\right)} K_{j i, T} \\
& +\frac{\left(\alpha_{c} t_{i}^{c}-\alpha_{g}\right)\left(1-t_{j}^{k}\right)}{\left(1+t_{i}^{c}\right)\left(1-t_{i}^{k}\right)} E_{T}\left(K_{i j, T+1}\right)+\frac{\left(\alpha_{c} t_{i}^{c}-\alpha_{g}\right)}{\left(1+t_{i}^{c}\right)} E_{T}\left(K_{i i, T+1}\right) \\
& -\frac{\rho\left(\alpha_{c}+\alpha_{g}\right)}{\left(1+t_{i}^{c}\right)\left(1-t_{i}^{k}\right) R_{T}} B_{i, T}+\frac{\rho\left(\alpha_{c}+\alpha_{g}\right)\left(1+R_{T-1}\right)}{\left(1+t_{i}^{c}\right)\left(1-t_{i}^{k}\right) R_{T}} B_{i, T-1}=0
\end{aligned}
$$

Therefore, Equations (17), (A3), and (B1) show that the optimal nominal public debt level in country (i) during period $(\mathrm{T})$ in proportion of GDP is as follows:

$$
\begin{aligned}
\left(\frac{B_{i, T}}{P_{i, T} Y_{i, T}}\right)= & \frac{\left(1+R_{T-1}\right)\left(K_{i i, T-1}+K_{j i, T-1}\right) R_{T-1}}{\left(K_{i i, T}+K_{j i, T}\right) R_{T}}\left(\frac{B_{i, T-1}}{P_{i, t-1} Y_{i, T-1}}\right) \\
& -\frac{\alpha_{c}\left(1+t_{i}^{c}\right)\left(\rho-\rho \nu-\nu \delta t_{i}^{k}+\nu \delta t_{i}^{k 2}+\nu \rho t_{i}^{k}\right)}{\rho\left(\alpha_{c}+\alpha_{g}\right)}+\left(1-t_{i}^{l}\right)(1-\nu) \\
& -\frac{\nu\left(\alpha_{g}-\alpha_{c} c_{i}^{c}\right)\left(1-t_{i}^{k}\right)}{\rho\left(\alpha_{c}+\alpha_{g}\right)\left(K_{i i, T}+K_{j i, T}\right)}\left[E_{T}\left(K_{i i, T+1}\right)-\left(1+\rho-2 \delta+\delta t_{i}^{k}\right) K_{i i, T}\right] \\
& -\frac{\nu\left(\alpha_{g}-\alpha_{c} c_{i}^{c}\right)\left(1-t_{j}^{k}\right)}{\rho\left(\alpha_{c}+\alpha_{g}\right)\left(K_{i i, T}+K_{j i, T}\right)}\left[E_{T}\left(K_{i j, T+1}\right)-\left(1+\rho-2 \delta+\delta t_{j}^{k}\right) K_{i j, T}\right]
\end{aligned}
$$

Therefore, we have the following derivatives of this optimal nominal public debt-GDP ratio according to our model's various parameters:

$$
\begin{aligned}
& \frac{\partial\left(\frac{B_{i, T}}{P_{i, T} Y_{i, T}}\right)}{\partial\left(\frac{K_{i h, T}}{K_{i, T}}\right)}=-\frac{\nu\left(\alpha_{c} t_{i}^{c}-\alpha_{g}\right)\left(1-t_{h}^{k}\right)\left(\rho-2 \delta+\delta t_{h}^{k}\right)}{\rho\left(\alpha_{c}+\alpha_{g}\right)} \\
& \frac{\partial\left(\frac{B_{i, T}}{P_{i, T} Y_{i, T}}\right)}{\partial\left[\frac{E_{T}\left(K_{i h, T+1}\right)-K_{i h, T}}{K_{i, T}}\right]}=\frac{\nu\left(\alpha_{c} t_{i}^{c}-\alpha_{g}\right)\left(1-t_{h}^{k}\right)}{\rho\left(\alpha_{c}+\alpha_{g}\right)} \quad h=i \text { or } j
\end{aligned}
$$




$$
\begin{aligned}
\frac{\partial\left(\frac{B_{i, T}}{P_{i, T} Y_{i, T}}\right)}{\partial \rho}= & \frac{\nu \delta\left(1-t_{i}^{k}\right)\left[\alpha_{g}\left(2-t_{i}^{k}\right)-\alpha_{c}\left(2 t_{i}^{c}+t_{i}^{k}\right)\right]}{\rho^{2}\left(\alpha_{c}+\alpha_{g}\right)} \\
& -\frac{\nu\left(\alpha_{g}-\alpha_{c} c_{i}^{c}\right)\left(1-t_{i}^{k}\right)}{\rho^{2}\left(\alpha_{c}+\alpha_{g}\right)\left(K_{i i, T}+K_{j i, T}\right)}\left[\delta\left(2-t_{i}^{k}\right) K_{j i, T}-E_{T}\left(K_{i i, T+1}\right)+K_{i i, T}\right] \\
& +\frac{\nu\left(\alpha_{g}-\alpha_{c} c_{i}^{c}\right)\left(1-t_{j}^{k}\right)}{\rho^{2}\left(\alpha_{c}+\alpha_{g}\right)\left(K_{i i, T}+K_{j i, T}\right)}\left[\delta\left(2-t_{j}^{k}\right) K_{i j, T}+E_{T}\left(K_{i j, T+1}\right)-K_{i j, T}\right] \\
\frac{\partial\left(\frac{B_{i, T}}{\left.P_{i, T} Y_{i, T}\right)}=\right.}{\partial \nu}= & -\frac{\left(\left(2 t_{i}^{c}+t_{i}^{k}\right) \delta \alpha_{c}\left(1-t_{i}^{k}\right)-\left(2-t_{i}^{k}\right) \delta \alpha_{g}\left(1-t_{i}^{k}\right)+\rho\left(t_{i}^{l}-t_{i}^{k}\right)\left(\alpha_{c}+\alpha_{g}\right)\right]}{\rho\left(\alpha_{c}+\alpha_{g}\right)} \\
& +\frac{\left(\alpha_{g} t_{i}^{c}\right)\left(1-\alpha_{g}\right)\left(K_{i i, T}+t_{i}^{c}\right)\left(1-K_{j i, T}^{k}\right)}{\rho\left(\alpha_{c}+\alpha_{g}\right)\left(K_{i i, T}+K_{j i, T}\right)}\left[\left(\rho-2 \delta+\delta t_{i}^{k}\right) K_{j i, T}+E_{T}\left(K_{i i, T+1}\right)-K_{i i, T}\right] \\
& +\frac{\nu\left(\alpha_{g}-\alpha_{c} c_{i}^{c}\right) \delta}{\rho\left(\alpha_{c}+\alpha_{g}\right)\left(K_{i i, T}+K_{j i, T}\right)}\left[\left(1-t_{i}^{k}\right)\left(2-t_{i}^{k}\right) K_{j i, T}-\left(1-t_{j}^{k}\right)\left(2-t_{j}^{k}\right) K_{i j, T}\right] \\
\frac{\partial\left(\frac{B_{i, T}}{P_{i, T} Y_{i, T}}\right)}{\partial \delta}= & \frac{\nu\left(1-t_{i}^{k}\right)\left[\alpha_{c}\left(t_{i}^{k}+2 \delta t_{i}^{c}\right)+\alpha_{c} t_{i}^{k} t_{i}^{c}(1-\delta)-\alpha_{g} \delta\left(2-t_{i}^{k}\right)\right]}{\rho\left(\alpha_{c}+\alpha_{g}\right)} \\
&
\end{aligned}
$$

This value is mostly positive with a plausible calibration of our parameters as the preference for private consumption $\left(\alpha_{c}\right)$ is sufficiently high compared with the preference for public consumption $\left(\alpha_{g}\right)$, and as the differential between foreign investments realized by both countries and the second term of the expression can be significantly negligible compared with investment in the national country.

$$
\begin{aligned}
\frac{\partial\left(\frac{B_{i, T}}{P_{i, T} Y_{i, T}}\right)}{\partial\left(\frac{\alpha_{g}}{\alpha_{c}}\right)}= & \frac{\left(1+t_{i}^{c}\right)}{\rho\left(K_{i i, T}+K_{j i, T}\right)}\left(\frac{\alpha_{c}}{\alpha_{c}+\alpha_{g}}\right)^{2}\left[\left(\rho-2 \nu \delta+2 \nu \delta t_{i}^{k}\right)\left(K_{i i, T}+K_{j i, T}\right)-\nu\left(1-t_{i}^{k}\right)\left(\rho-2 \delta+\delta t_{i}^{k}\right) K_{j i, T}\right. \\
& +\nu\left(1-t_{j}^{k}\right)\left(\rho-2 \delta+\delta t_{j}^{k}\right) K_{i j, T}-\nu\left(1-t_{j}^{k}\right) E_{T}\left(K_{i j, T}+1\right)+\nu\left(1-t_{j}^{k}\right) K_{i j, T} \\
& \left.\left.-\nu\left(1-t_{i}^{k}\right) E_{T}\left(K_{i i, T+1}\right)+\nu\left(1-t_{i}^{k}\right) K_{i i, T}\right]\right\}
\end{aligned}
$$

This expression is mostly positive, if $\left(K_{i i, T+1} \sim K_{i i, T}\right),\left(K_{i j, T+1} \sim K_{i j, T}\right),\left(K_{i j, T} \sim K_{j i, T}\right)$. 


$$
\begin{aligned}
\frac{\partial\left(\frac{B_{i, T}}{P_{i, T} Y_{i, T}}\right)}{\partial t_{i}^{c}}= & -\frac{\alpha_{c}}{\rho\left(\alpha_{c}+\alpha_{g}\right)\left(K_{i i, T}+K_{j i, T}\right)}\left[\left(\rho-2 \nu \delta+2 \nu \delta t_{i}^{k}\right)\left(K_{i i, T}+K_{j i, T}\right)\right. \\
& +\nu\left(1-t_{j}^{k}\right)\left(\rho-2 \delta+\delta t_{j}^{k}\right) K_{i j, T}-\nu\left(1-t_{i}^{k}\right)\left(\rho-2 \delta+\delta t_{i}^{k}\right) K_{j i, T} \\
& \left.-\nu\left(1-t_{i}^{k}\right) E_{T}\left(K_{i i, T+1}\right)+\nu\left(1-t_{i}^{k}\right) K_{i i, T}-\nu\left(1-t_{j}^{k}\right) E_{T}\left(K_{i j, T+1}\right)+\nu\left(1-t_{j}^{k}\right) K_{i j, T}\right]
\end{aligned}
$$

This expression is mostly negative, if $\left(K_{i i, T+1} \sim K_{i i, T}\right),\left(K_{i j, T+1} \sim K_{i j, T}\right),\left(K_{i j, T} \sim K_{j i, T}\right)$.

$$
\begin{aligned}
\frac{\partial\left(\frac{B_{i, T}}{P_{i, T} Y_{i, T}}\right)}{\partial t_{i}^{l}}= & -(1-\nu)<0 \\
\frac{\partial\left(\frac{B_{i, T}}{P_{i, T} Y_{i, T}}\right)}{\partial t_{i}^{k}}= & -\frac{\nu}{\rho\left(\alpha_{c}+\alpha_{g}\right)\left(K_{i i, T}+K_{j i, T}\right)}\left[\alpha_{c}\left(1+t_{i}^{c}\right)\left(\rho-\delta+2 \delta t_{i}^{k}\right)\left(K_{i i, T}+K_{j i, T}\right)\right. \\
& +\left(\alpha_{g}-\alpha_{c} t_{i}^{c}\right)\left(\rho-3 \delta+2 \delta t_{j}^{k}\right) K_{i j, T}+\left(\alpha_{g}-\alpha_{c} t_{i}^{c}\right)\left(\rho-3 \delta+2 \delta t_{i}^{k}\right) K_{i i, T} \\
& -\left(\alpha_{g}-\alpha_{c} t_{i}^{c}\right) E_{T}\left(K_{i i, T+1}\right)+\left(\alpha_{g}-\alpha_{c} t_{i}^{c}\right) K_{i i, T} \\
& \left.\left.-\left(\alpha_{g}-\alpha_{c} t_{i}^{c}\right) E_{T}\left(K_{i j, T+1}\right)+\left(\alpha_{g}-\alpha_{c} t_{i}^{c}\right) K_{i j, T}\right]\right\}
\end{aligned}
$$

This expression is mostly negative, if $\left(K_{i i, T+1} \sim K_{i i, T}\right),\left(K_{i j, T+1} \sim K_{i j, T}\right),\left(\alpha_{g}>\alpha_{c} t_{i}^{c}\right)$.

$$
\frac{\partial\left(\frac{B_{i, T}}{P_{i, T} Y_{i, T}}\right)}{\partial\left(t_{i}^{k}-t_{j}^{k}\right)}=\frac{\nu\left(\alpha_{g}-\alpha_{c} t_{i}^{c}\right)}{\rho\left(\alpha_{c}+\alpha_{g}\right)\left(K_{i i, T}+K_{j i, T}\right)}\left[\left(1+\rho-3 \delta+2 \delta t_{j}^{k}\right) K_{i j, T}-E_{T}\left(K_{i j, T+1}\right)\right]
$$




\section{Appendix C: Taxation Rates and Public Debt Levels}

Capital tax rates and public debt levels
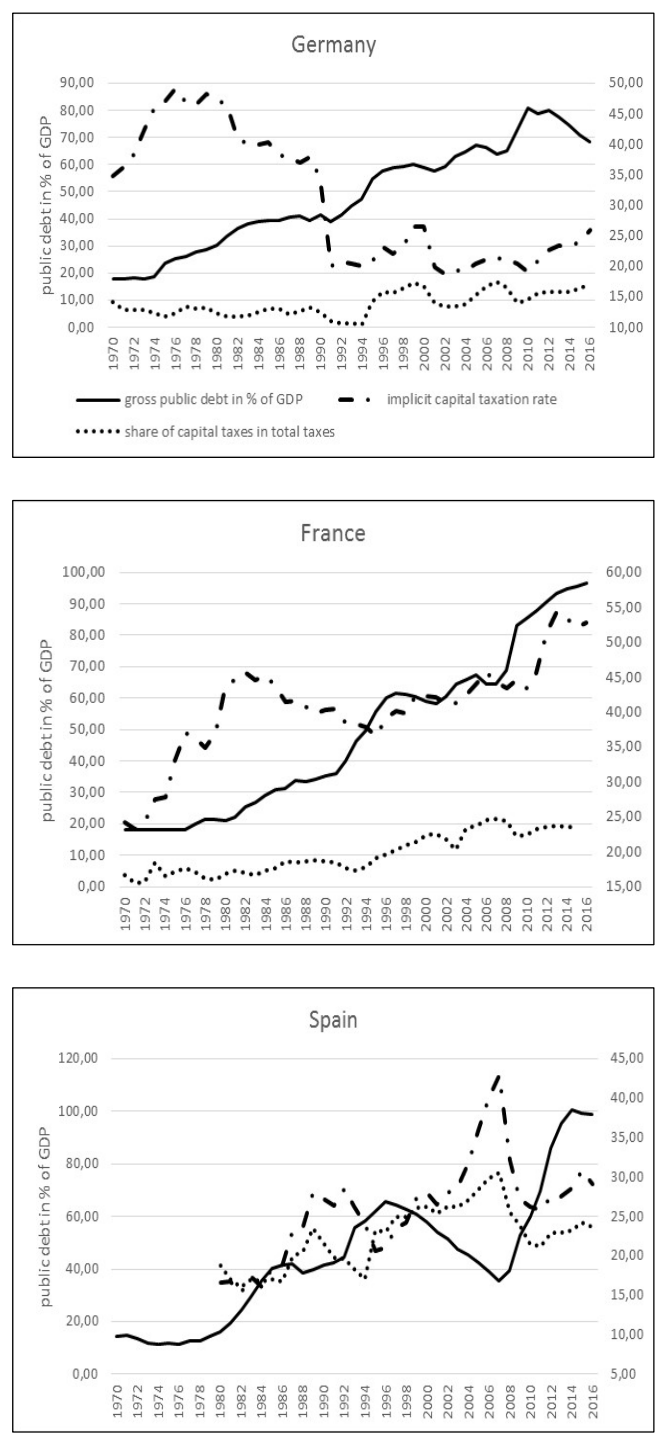
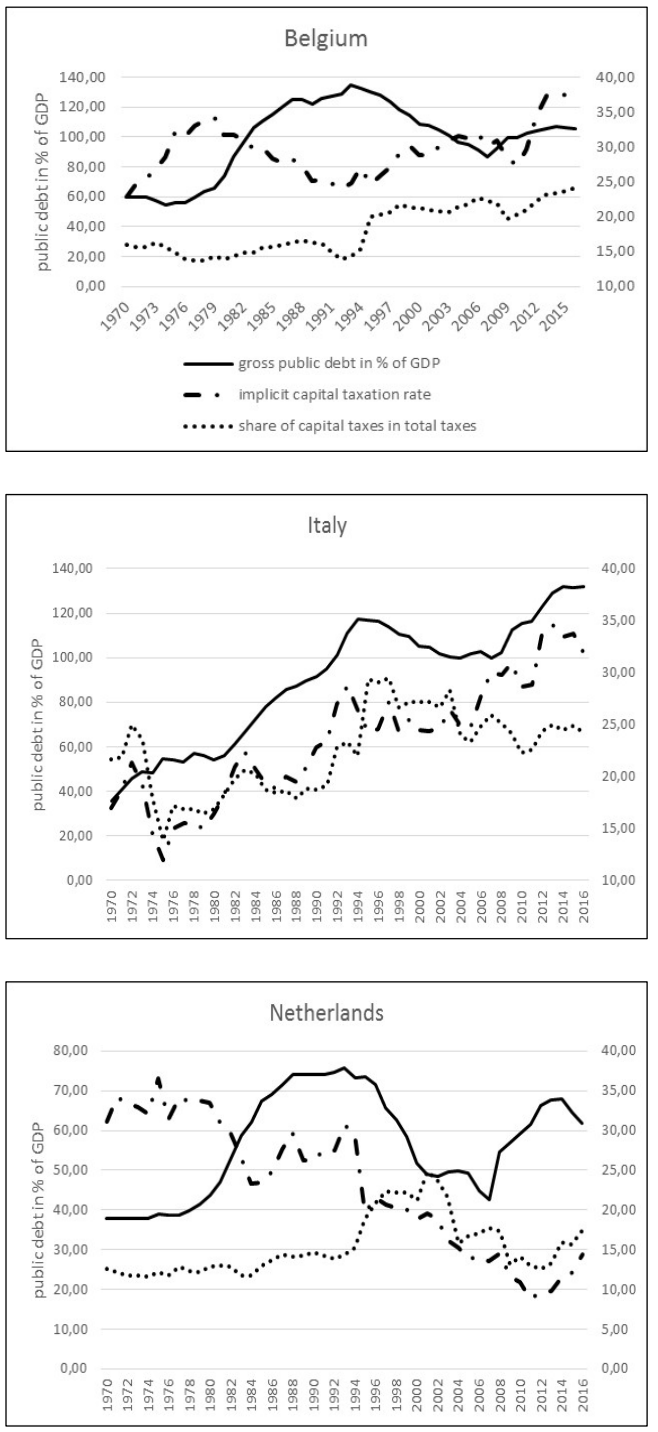


\section{Labor tax rates and public debt levels}
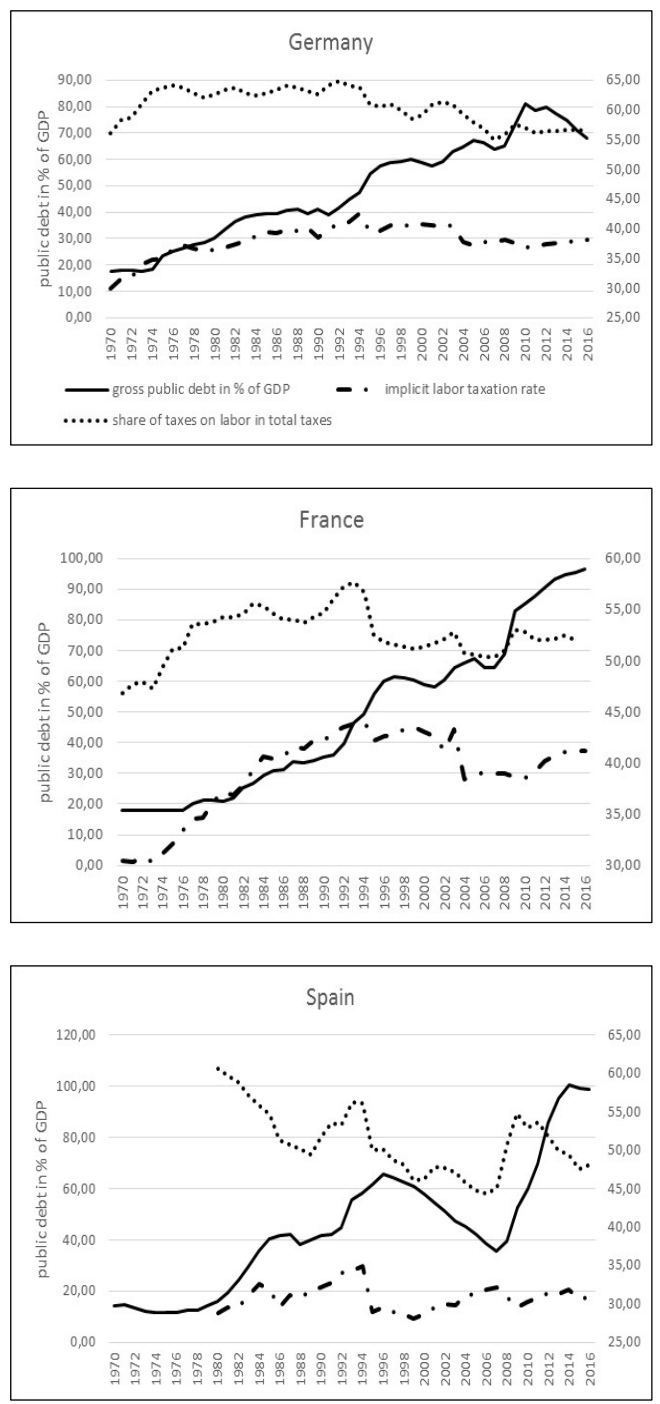
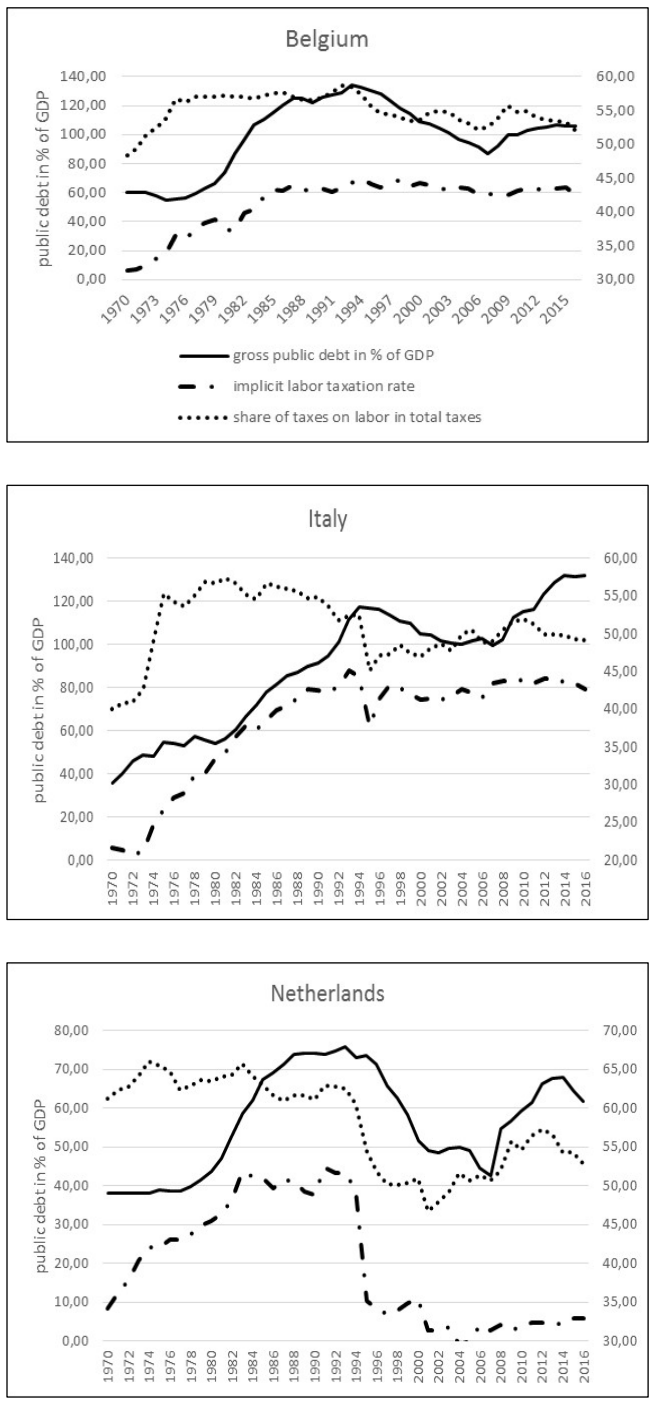


\section{Consumption tax rates and public debt levels}
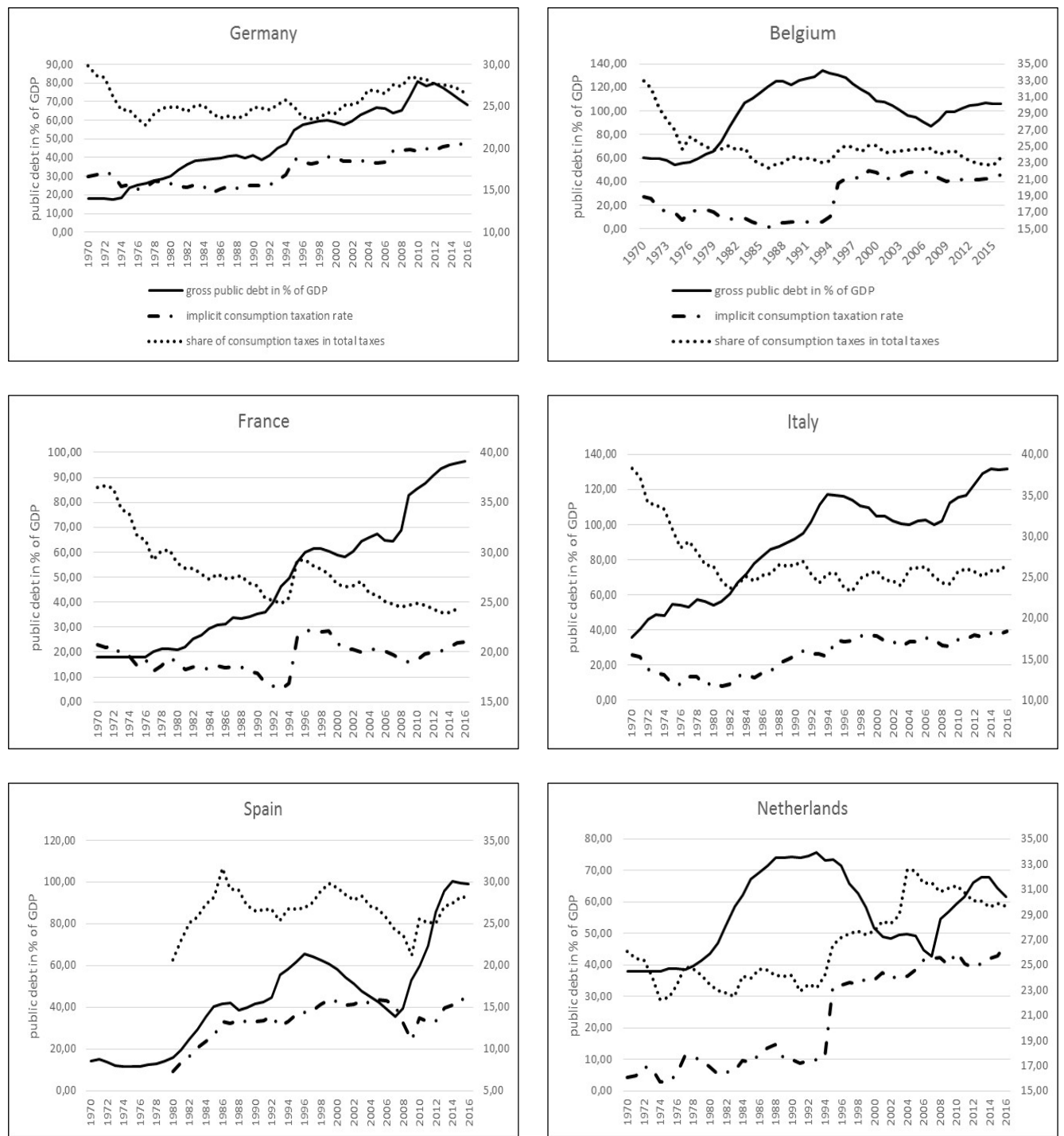

(Source) For taxation rates: European Commission (2000, 2005, 2018), "Taxation trends in the EU- Data for the EU member States, Iceland and Norway," Eurostat, European Commission.

For public debt levels: EUROSTAT. 